\title{
Synthesis, vibrational and thermal properties of new functionalized 1- (2-hydroxyethyl) -3-methylimidazolium dihydrogenophosphate ionic liquid.
}

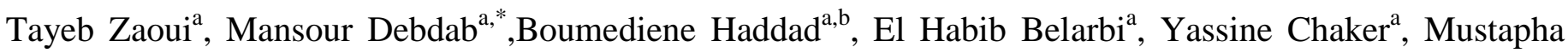
Rahmouni $^{\mathrm{a}}$, Serge Bresson ${ }^{\mathrm{c}}$, Vincent Baeten ${ }^{\mathrm{d}}$

${ }^{a}$ Synthesis and Catalysis Laboratory (LSCT), University of Tiaret, Faculty of Materials Sciences, Tiaret, Algeria.

${ }^{b}$ Chemistry Laboratory of Synthesis, Properties, and Applications (CLSPA-Saida), University of Saida, Algeria.

${ }^{c}$ UP Transformations \& Agro-Ressources, Institut Polytechnique UniLaSalle, URL 7519, 19 Rue Pierre Waguet, BP 30313, F-60026 Beauvais CEDEX, France.

${ }^{d}$ Centre Wallon de Recherche Agronomique, CRA-W, Bâtiment Maurice Henseval, chaussée de Namur, 24, 5030 Gembloux, Belgium.

\begin{abstract}
:
Very recently, the hydroxyl-functionalized ionic liquids have gained immense interest and were developed for a number of interesting applications.In this work and for the first time new hydroxyl-functionalized namely; 1-(hydroxyethyl)-3-methylimidazoliumdihydrogenophosphateionic liquid $\left[\mathrm{EtOHMIM}^{+}\right]\left[\mathrm{H}_{2} \mathrm{PO}_{4}{ }^{-}\right]$ was synthesized in our laboratory. The synthesis is based on an alkylation reaction of 1-methylimidazole followed by anion exchange. The obtained IL is characterized by ${ }^{1} \mathrm{H}-\mathrm{NMR},{ }^{13} \mathrm{C}-\mathrm{NMR}$ spectroscopy. This experimental vibrational spectroscopy have been investigated using Infrared and Raman spectroscopy, based on the infrared (IR) and Raman spectroscopies results, complete vibrational assignments have been performed. Besides, thermal properties of this hydroxyl-functionalized IL were investigated by using following techniques, (i) Thermogravimetric Analysis (TGA) and Derivative Thermogravimetry (DTG) in the temperature range from 20 to $600 \mathrm{C}^{\circ}$, (ii) differential scanning calorimetry (DSC) from-100 ${ }^{\circ} \mathrm{C}$ to 200 ${ }^{\circ} \mathrm{C}$. The thermogravimetry analysis was coupled with mass spectrometry in order to assess the influence of anion on the measured property.
\end{abstract}

KEYWORDS: Hydroxyl-functionalized ionic liquids; dihydrogenophosphate anion; NMR spectra; IR spectra; RAMAN spectra; thermal stability.

* Corresponding author E- mail: (mansour.debdab@ univ-tiaret.dz)

Mail Adress: Synthesis and Catalysis Laboratory (LSCT), University of Tiaret, Faculty of Materials Sciences, P.O.BOX 78 RP 1400 Tiaret, Algeria

\section{https://doi.org/10.1016/j.molstruc.2021.130264}




\section{Introduction:}

In the early 1990's, for the vast majority of chemists, the term ionic liquid was obscure and little known. Since 2000, the research in this area has been focused and greatly expanded. Indeed, their physicochemical properties are very interesting and varied, and the multiple possibly applications in organic chemistry make these entities the compounds of choice as substitute solvents for catalysis [1-2] and supported synthesis [34]. In addition, the physical and chemical properties of the Ionic Liquids (ILs) are modifiable by varying the anion / cation combinations. This enabled the design of systems adaptable to various applications (electrochemistry, organic, inorganic and enzymatic synthesis, catalysis ...) but also to adjust the physicochemical properties of these organic salts according to needs.

In this area, several works focused on the synthesis and application of new class of ionic liquids, namely; hydroxyl functionalized ionic liquids containing, bromide, chloride, iodide, tetrafluoroborate,picrate, hexafluorophosphate,bis(trifluoromethylsulfonyl)imide, nitrate, alkyl sulfates, dicyanamide, thiocynate, and trifluoromethanesulfate anions[5-13].Compared to the traditional ILs, this class of ILs have received much attention in many applications, especially in the fields of catalysis [14], biotechnology[15], sonochemistry[16] andorganic synthesis [17].

In this respect and at spectroscopic point of view, there are extensive works published in this area (see Ref. [18] and references therein), However, compared to the hydroxyl functionalized ionic liquids already synthesized and published and to the best of our knowledge, there are no reports in the literature dealing the synthesis, thermal and vibrational spectroscopy of 1-(hydroxyethyl)-3methylimidazoliumdihydrogenophosphate $\left[\mathrm{EtOHMIM}^{+}\right]\left[\mathrm{H}_{2} \mathrm{PO}_{4}^{-}\right]$. This inorganic anion used in numerous analytical methods andis one of the anions in the dissociation equilibrium of phosphoric acid dissolved in water[19-20].

Very recently, we have investigated the vibrational and thermal properties of 1- (hydroxyethyl)-3methylimidazolium cation coupled with sulphate and chloride anion [21]by using IR /Raman spectroscopic and thermal analysis. In this work, we thought to synthesize this functionalized ionic liquid but with dihydrogenophosphate $\left[\mathrm{H}_{2} \mathrm{PO}_{4}^{-}\right]$anion there are no reports in the spectroscopic literature dealing to the vibrational spectroscopy of1-(hydroxyethyl)-3-methylimidazolium with this anion.

On the other hand and contrary to that published with this cation, the synthesis, vibrational spectroscopy and the thermal properties of this ionic liquid coupled with dihydrogenophosphate are not covered yet by the literature. In this framework, we have set out to prepare 1-(hydroxyéthyl)-3-methylimidazolium dihydrogeno phosphate. This new functionalized ionic liquid has been structurally identified using Nuclear magnetic resonance (NMR). Furthermore, infrared and Raman spectroscopy have been adopted to evaluate their 
vibrational spectroscopy properties. Finally; their thermal properties have been investigated by thermogravimetric analysis TGA, DTG and DSC.

In order to study the impact of the anion on the thermal and vibrational behavior, we show an example of $\left[\mathrm{EtOHMIM}^{+}\right]\left[\mathrm{Cl}^{-}\right]$to investigate these properties by comparison between chloride and dihydrogenophosphate $\left[\right.$ EtOHMIM$\left.{ }^{+}\right]\left[\mathrm{H}_{2} \mathrm{PO}_{4}{ }^{-}\right]$varying in their structural characteristics.

\section{Experimental part:}

\subsection{Materials and methods:}

\subsubsection{Synthesis and characterization of ILs:}

1-methylimidazole, 2-Chloroethanole, acetonitrile, diethyl ether is up to (99\% pure) from Sigma-Aldrich as starting reagentswere used in this work without any further purification.

The synthesis of 1-(hydroxyethyl)-3-methylimidazolium chloride [EtOHMIM$\left.{ }^{+}\right]\left[\mathrm{Cl}^{-}\right]$was reported in our recent study [21]. For the metathesis reaction a mixture of 1- (2-hydroxyethyl) -3-methylimidazolium chloride (5 g, $0.0252 \mathrm{~mol})$ and ortho-phosphoric acid $(08 \mathrm{ml}, 0.062 \mathrm{~mol})$ was carried out at room temperature for $24 \mathrm{~h}$ with vigorous magnetic stirring in $30 \mathrm{ml}$ acetonitrile. The crude was washed with diethyl ether ( $3 \times 80 \mathrm{ml})$ after elimination of acetonitrile and then concentrated on a rotary evaporator under reduced pressureyielding a pale viscous yellow liquid. Finally, in order to obtain high purity and to remove any possible water contamination before their use, our obtained ionic liquid was dried under vacuum $\left(10^{3-}\right.$ bar). The yield of this reaction was $(98 \%)$. The general procedure for the synthesis of 1-(hydroxyethyl)-3methylimidazoliumdihydrogenophosphate[EtOHMIM $\left.{ }^{+}\right]\left[\mathrm{H}_{2} \mathrm{PO}_{4}{ }^{-}\right]$is summarized in Scheme $\mathbf{1}$.

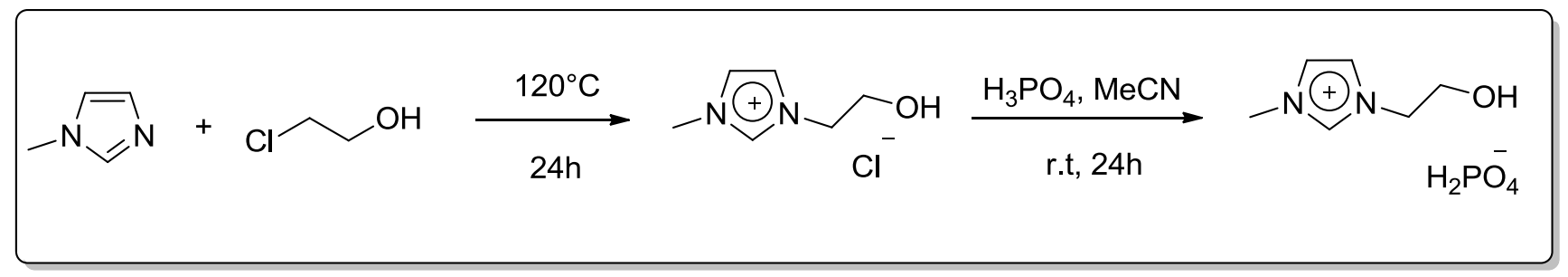

Scheme 1. Synthetic route of $\left[\mathrm{EtOHMIM}^{+}\right]\left[\mathrm{H}_{2} \mathrm{PO}_{4}^{-}\right]$.

\subsection{NMR spectroscopy analysis:}

The structure and purity of our investigated functionalized ILs were confirmed by spectral analysis: ${ }^{1} \mathrm{H}$ and ${ }^{13} \mathrm{C}$ NMR spectra were recorded on a Bruker Biospin Avance III spectrometer equipped with a 5 mm TXI probe at 600 and $300 \mathrm{MHz}$, respectively. Chemical shifts $(\delta)$ are given in ppm and referenced to the internal signal solvent $\mathrm{D}_{2} \mathrm{O}$ and DMSO. The spectroscopic data are given below. 


\subsubsection{1-(hydroxyethyl)-3-methylimidazoliumchloride [EtOHMIM+ $]\left[\mathrm{Cl}^{-}\right]$}

${ }^{1} \mathbf{H}-N M R\left(600 ~ M H z, D_{2} \mathbf{O}\right): \boldsymbol{\delta}=9.36(\mathrm{~s}, 1 \mathrm{H}, \mathrm{H}-2) ; 9.08$ (sl, 1H, OH); 7.82 (s, 1H, H-4or H-5); 7.79 (s, 1H, H-4or H-5); 4.25 (t, 2H, NCH $)$; 3.88 (s, 3H, $\mathrm{NCH}_{3}$ ); 3.69(t, 2H, $\mathrm{CH}_{2} \mathrm{OH}$ ) (see Figure.1.a). ${ }^{13} \mathbf{C}-\mathbf{N M R}$ (600 MHz, $\left.\mathbf{D}_{2} \mathbf{O}\right): \boldsymbol{\delta}=137.33(\mathrm{C}-2) ; 123.70$ and $123.10(\mathrm{C}-4$ and $\mathrm{C}-5) ; 59.71\left(\mathrm{~N}_{\mathbf{C}}\right) ; 51.94\left(\underline{\mathbf{C H}}_{2} \mathrm{O}\right) ; 36.12$ $\left(\mathrm{N}_{\mathrm{CH}}\right)($ seeFigure.1.b).

\subsubsection{1-(hydroxyethyl)-3-methylimidazolium dihydrogenophosphate $\left[\right.$ EtOHMIM$\left.{ }^{+}\right]\left[\mathrm{H}_{2} \mathrm{PO}_{4}{ }^{-}\right]$}

${ }^{1}$ H-NMR (300 MHz, DMSO): $\boldsymbol{\delta}=9.21$ (s, 1H, H-2); 7.75 (s, 1H, H-4 or H-5); 7.71 (s, 1H, H-4 or H-5); 6.70 (sl, 1H, OH); 4.23 (t, 2H, NCH $) ; 3.86$ (s, 3H, NCH $)$; 3.69 (t, 2H, $\mathrm{CH}_{2} \mathrm{OH}$ ) (see Figure.2.a). ${ }^{\mathbf{1 3}} \mathbf{C}$ NMR (300 MHz, DMSO): $\boldsymbol{\delta}=137.23$ (C-2); 123.7 and 123.08 (C-4 and C-5); $59.74\left(\mathrm{~N}_{\mathbf{C H}}\right) ; 51.96$ $\left(\underline{\mathbf{C H}}_{2} \mathrm{O}\right) ; 36.12\left(\mathrm{~N}_{\mathbf{C}} \mathrm{H}_{3}\right)$ (seeFigure.2.b).

\subsection{FTIR/ATR measurements}

The samples measurements were performed in the Walloon Agricultural Research Center (CRA-W) Belgium. Fourier Transform mid-infrared All attenuated total reflectance (FTIR /ATR) measurements were acquired on a Bruker Vertex II-70 RAM Spectrometer (Bruker Analytical, Madison, WI) operating with a Golden Gate diamond ATR accessory TM (Specac Ltd, Slough, United Kingdom). FTIR/ATR spectra [4000-600 $\mathrm{cm}^{-1}$ ] were collected with a resolution of $1 \mathrm{~cm}^{-1}$ by co-adding 64 scans for each spectrum. The OPUS Software 6.0 was used for the management of the instrument.

\subsection{FT-Raman measurements}

These measurements were also carried out in the Walloon Agricultural Research Center (CRA-W) in Belgium. The FT-Raman spectra were acquired on a Vertex 70-RAM II Bruker FT-Raman spectrometer. This instrument is equipped with a Nd:YAG laser (yttrium aluminum garnet crystal doped with triply ionized neodymium)with a wavelength of $1064 \mathrm{~nm}$ and a maximum power of $1.5 \mathrm{~W}$. The measurement accessory is pre-aligned: only the Z-axis of the scattered light is adjusted to set the sample in the appropriate position regarding the local measurement point. The RAM II spectrometer is equipped with a liquid nitrogen

cooled Gedetector.FT-Raman spectra [4000-45 $\mathrm{cm}^{-1}$ ] were collected with a resolution of $1 \mathrm{~cm}^{-1}$ by co-adding 128 scans for each spectrumat room temperature. The OPUS 6.0 software was used for the spectral acquisition, manipulation and transformation.

\subsection{Thermal measurements}

Thermal gravimetric (TGA) and DTG measurements were performed using a NETZSCH STA 449 C (TGADSC) $\left(20^{\circ} \mathrm{C}\right.$ to $\left.1500{ }^{\circ} \mathrm{C}\right)$ apparatus coupled to a mass spectrometer for analyzing the gas, with a heating rate 
of $5^{\circ} \mathrm{C} / \mathrm{min}$ in a temperature range of $20^{\circ} \mathrm{C}$ to $400{ }^{\circ} \mathrm{C}$ under Argon. The characterization by DSC was carried out with a Differential calorimetry system (NETZSCH DSC 204 F1) with a speed of heating and cooling of $5^{\circ} \mathrm{C} / \mathrm{min}$, by performing two heating and cooling cycles to remove traces of water and solvent in a temperature range of $\left(-100^{\circ} \mathrm{C}\right.$ to $\left.200{ }^{\circ} \mathrm{C}\right)$ under Argon. The experimental procedure is as follows:

- Cooling from $25{ }^{\circ} \mathrm{C}$ to $-100{ }^{\circ} \mathrm{C}$, leaving the sample at this temperature for 5 minutes

- Heating from $-100{ }^{\circ} \mathrm{C}$ to $120^{\circ} \mathrm{C}$

- Cooling from $120^{\circ} \mathrm{C}$ to $-100{ }^{\circ} \mathrm{C}$ leaving the sample at this temperature for 5 minutes

- Heating from $-100{ }^{\circ} \mathrm{C}$ to $200{ }^{\circ} \mathrm{C}$

\section{Results and discussion}

\subsection{NMR spectroscopy characterization}

In order to identify and confirmed the structures of obtained ILs, the ionic liquids skeletons $\left[\mathrm{EtOHMIM}^{+}\right]\left[\mathrm{Cl}^{-}\right]$and $\left[\mathrm{EtOHMIM}^{+}\right]\left[\mathrm{H}_{2} \mathrm{PO}_{4}^{-}\right]$have been characterized structurally using Nuclear magnetic resonance ${ }^{1} \mathrm{H}$ and ${ }^{13} \mathrm{C}$-NMR spectroscopy, which confirms the absence of any impurities. The resulting spectra are presented in Figures 1-2, in the ${ }^{1} \mathrm{H}-\mathrm{NMR}$ spectra of $\left[\mathrm{EtOHMIM}^{+}\right]\left[\mathrm{Cl}^{-}\right]$and $\left[\mathrm{EtOHMIM}^{+}\right]\left[\mathrm{H}_{2} \mathrm{PO}_{4}{ }^{-}\right.$ ],the signals at $\delta_{\mathrm{H}}=9.36 \mathrm{ppm}$ and at $\delta_{\mathrm{H}}=9.21 \mathrm{ppm}$ corresponds to the $\mathrm{C} 2-\mathrm{H}$ of imidazolium ring protons, respectively. For the proton of imidazolium ring: $\mathrm{C}_{4}-\mathrm{H}$ and $\mathrm{C}_{5}-\mathrm{H}$ were displayed at $\delta_{\mathrm{H}}=7.82 / 7.79 \mathrm{ppm}$ for $\left[\mathrm{EtOHMIM}^{+}\right]\left[\mathrm{Cl}^{-}\right]$and at $\delta_{\mathrm{H}}=7.75 / 7.71 \mathrm{ppm}$ for $\left[\mathrm{EtOHMIM}^{+}\right]\left[\mathrm{H}_{2} \mathrm{PO}_{4}{ }^{-}\right]$. Signatures of $\left(\mathrm{N}-\mathrm{CH}_{2}-\right)$ protons found at $\delta_{\mathrm{H}}=4.25 \mathrm{ppm}$ in $\left[\mathrm{EtOHMIM}^{+}\right]\left[\mathrm{Cl}^{-}\right]$, while it's appeared at $\delta_{\mathrm{H}}=4.23 \mathrm{ppm}$ in $\left[\mathrm{EtOHMIM}^{+}\right]\left[\mathrm{H}_{2} \mathrm{PO}_{4}{ }^{-}\right]$. Bisedes, the characteristic peak for $\mathrm{N}$-methyl protons $\left(\mathrm{N}-\mathrm{CH}_{3}\right)$ appeared at $\delta_{\mathrm{H}}=3.88 / 3.86 \mathrm{ppm}$ in $\left[\mathrm{EtOHMIM}^{+}\right]\left[\mathrm{Cl}^{-}\right]$and $\left[\mathrm{EtOHMIM}^{+}\right]\left[\mathrm{H}_{2} \mathrm{PO}_{4}^{-}\right]$respectively. Moreover, the resonance of the methylene protons $\left(-\mathrm{CH}_{2}-\mathrm{OH}\right)$ is observed at $\delta_{\mathrm{H}}=3.69 \mathrm{ppm}$ for both of ILs. As shown in Figures 1a and $2 \mathbf{a}$, the chemical shift $\mathrm{O}-\mathrm{H}$ groups was observed at $9.08 \mathrm{ppm}$ for $\left[\mathrm{EtOHMIM}^{+}\right]\left[\mathrm{Cl}^{-}\right]$and 6.70ppm for $\left[\mathrm{EtOHMIM}^{+}\right]\left[\mathrm{H}_{2} \mathrm{PO}_{4}{ }^{-}\right]$.This behavior related to the impact of electronegativity of each anion and also the charge transfer between 1-(hydroxyéthyl)-3-methylimidazoliumcation and both chloride and dihydrogenophosphate anions who plays a crucial role in the interionic interactions[22-25]. Additionally; two hydrogen's atoms are attached with $\left[\mathrm{PO}_{4}^{-}\right]$their signatures can only be found in $\left[\mathrm{EtOHMIM}^{+}\right]\left[\mathrm{H}_{2} \mathrm{PO}_{4}{ }^{-}\right]$, this is observed in the area of the $\mathrm{OH}$ peak in $\left[\mathrm{EtOHMIM}^{+}\right]\left[\mathrm{H}_{2} \mathrm{PO}_{4}{ }^{-}\right]$which shows a greater amplitude than that of $\mathrm{OH}$ in $\left[\mathrm{EtOHMIM}^{+}\right]\left[\mathrm{Cl}^{-}\right]$.

On the other hand, the ${ }^{13} \mathrm{C}-\mathrm{NMR}$ spectra of $\left[\mathrm{EtOHMIM}^{+}\right]\left[\mathrm{Cl}^{-}\right]$and $\left[\mathrm{EtOHMIM}^{+}\right]\left[\mathrm{H}_{2} \mathrm{PO}_{4}{ }^{-}\right]$show very clearly six signals between $\delta_{\mathrm{C}}=36.12$ and $137.33 \mathrm{ppm}$. Therefore, these spectral results confirm a high-purity of our investigated ILs. 


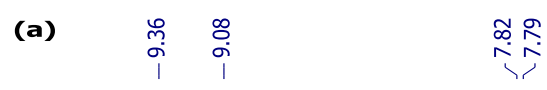

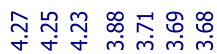
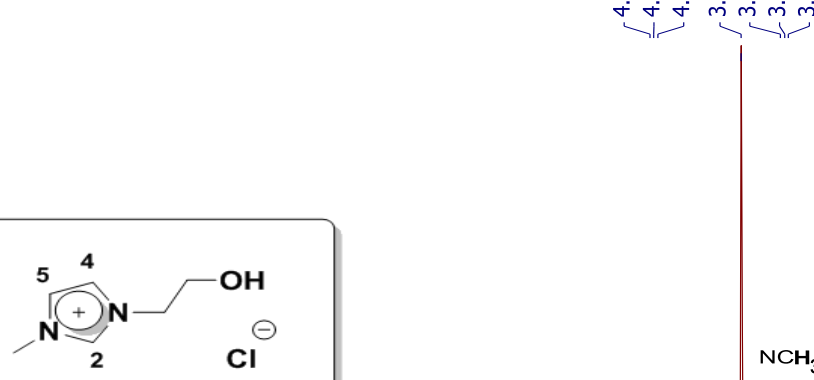

$\mathrm{NCH}_{3}$
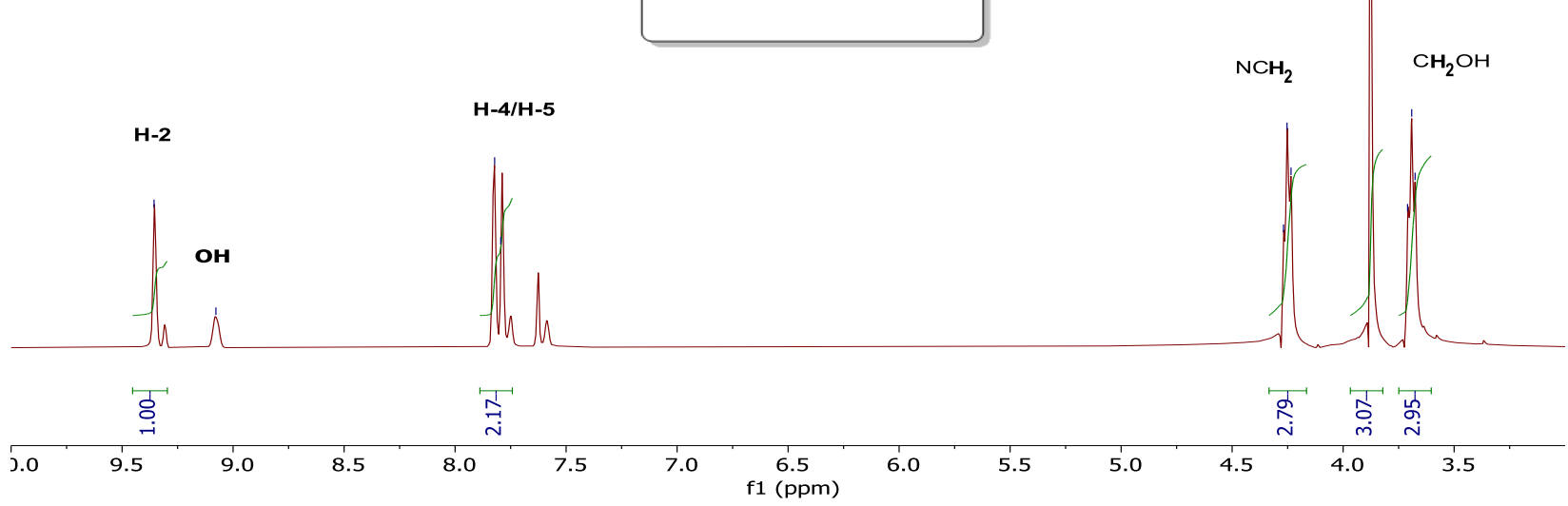

(b)

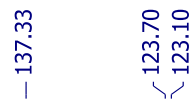

ㅎํㄹำ

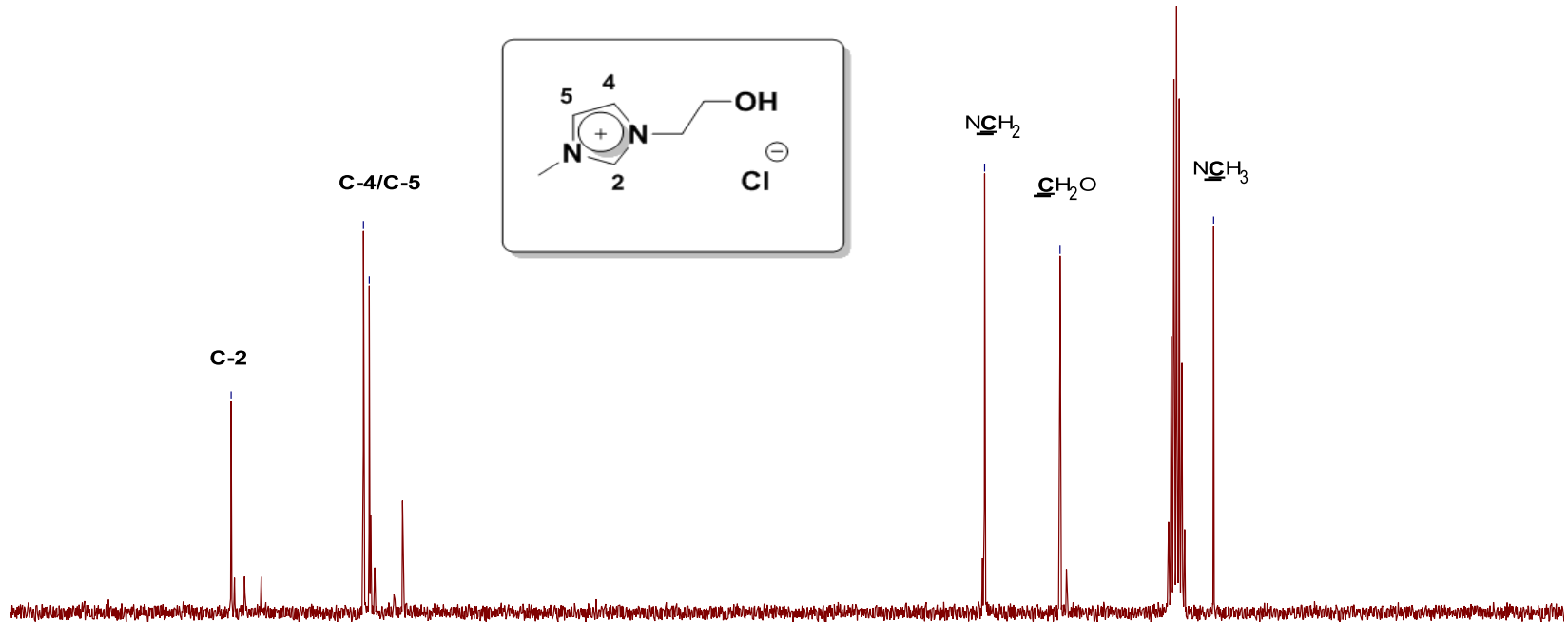

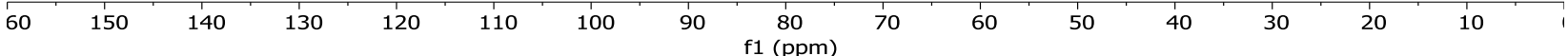

Figure.1: ${ }^{1} \mathrm{H}-\mathrm{NMR}(600 \mathrm{MHz})$ (a) and ${ }^{13} \mathrm{CNMR}(600 \mathrm{MHz})(\mathrm{b})$, spectra of $\left[\mathrm{EtOHMIM}^{+}\right]\left[\mathrm{Cl}^{-}\right]$. 
(a)

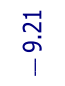

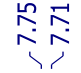

$R$
$i$
$i$

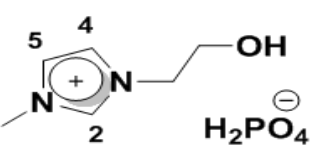

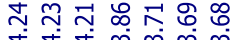

ナं

$\mathrm{NCH}_{3}$

H-4/H-5

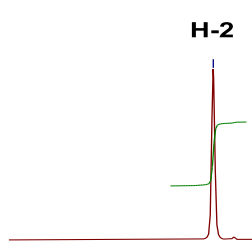

$-$

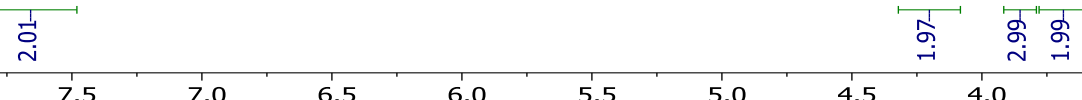

$8.5 \times 8.0$

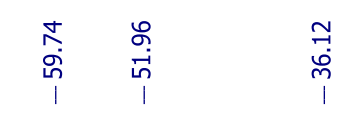

(b)

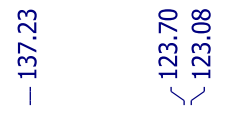

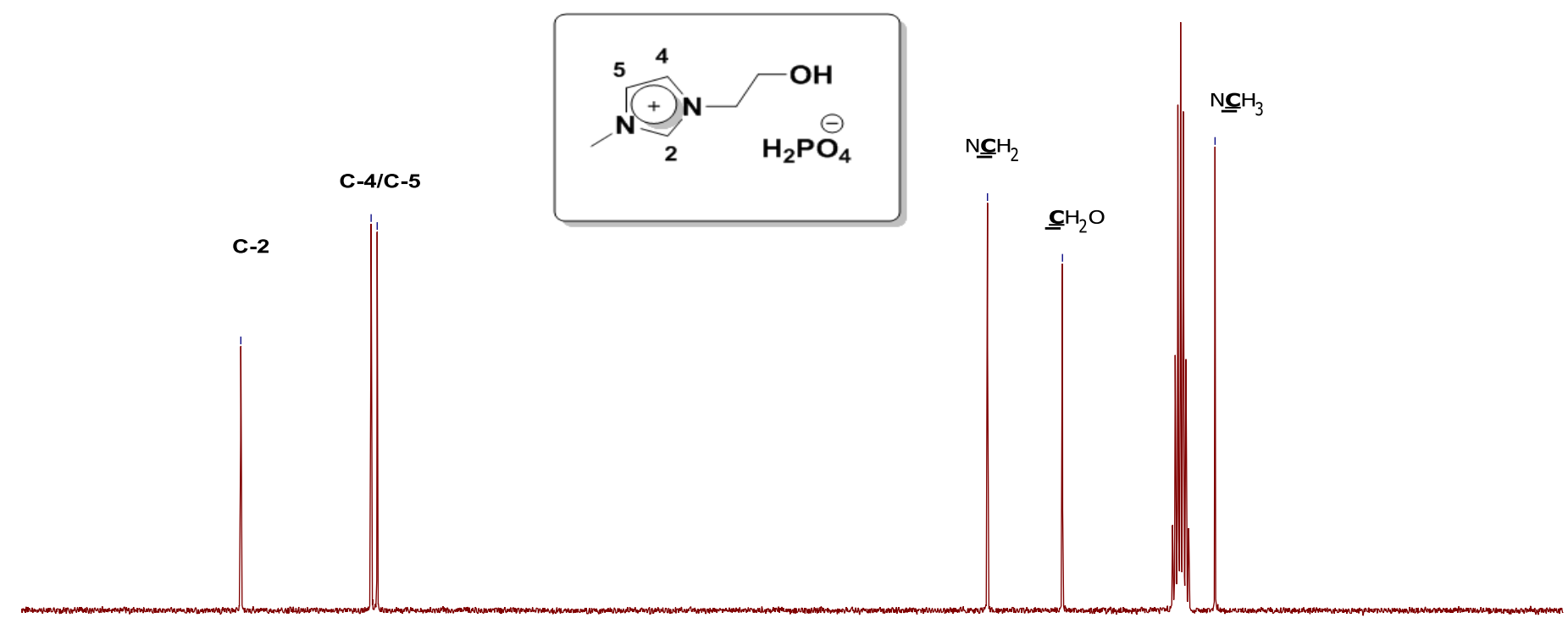

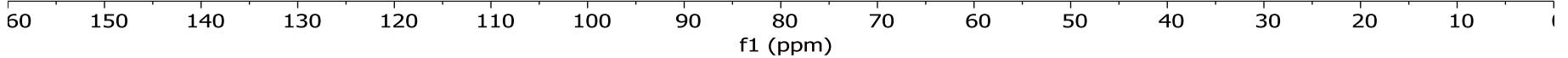

Figure.2. ${ }^{1} \mathrm{H}-\mathrm{NMR}(300 \mathrm{MHz})(\mathrm{a})$ and ${ }^{13} \mathrm{CNMR}(300 \mathrm{MHz})(\mathrm{b})$, spectra of $\left[\right.$ EtOHMIM$\left.{ }^{+}\right]\left[\mathrm{H}_{2} \mathrm{PO}_{4}{ }^{-}\right]$. 


\subsection{Experimental vibrational spectroscopy analysis}

In order to evaluate the effect of anions on the vibrational spectroscopic properties, FTIR/ATR and Raman spectra of this ionic liquid compared to 1-(hydroxyethyl)-3-methylimidazolium chloride $\left[\mathrm{EtOHMIM}^{+}\right]\left[\mathrm{Cl}^{-}\right.$ ]were measured and investigated in the wavenumber range $600-4000 \mathrm{~cm}^{-1}$ and from 45 to $3500 \mathrm{~cm}^{-1}$,

\subsubsection{The comparison between FTIR/ATR spectra of ionic liquids: 1-(hydroxyethyl)-3- methylimidazolium chloride $\left[\mathrm{EtOHMIM}^{+}\right]\left[\mathrm{Cl}^{-}\right]$and 1-(hydroxyethyl)-3-methylimidazolium dihydrogenophosphate $\left[\mathrm{EtOHMIM}^{+}\right]\left[\mathrm{H}_{2} \mathrm{PO}_{4}-\right]$.}

FTIR / ATR spectra [4000-600 $\mathrm{cm}^{-1}$ ] of the two ILs are illustrated in Figure.3. The observed IR bands and their detailed assignments are listed in Table 1. We distinguish three well defined spectral regions: 3500$2700,1700-1300$ and $1300-600 \mathrm{~cm}^{-1}$.

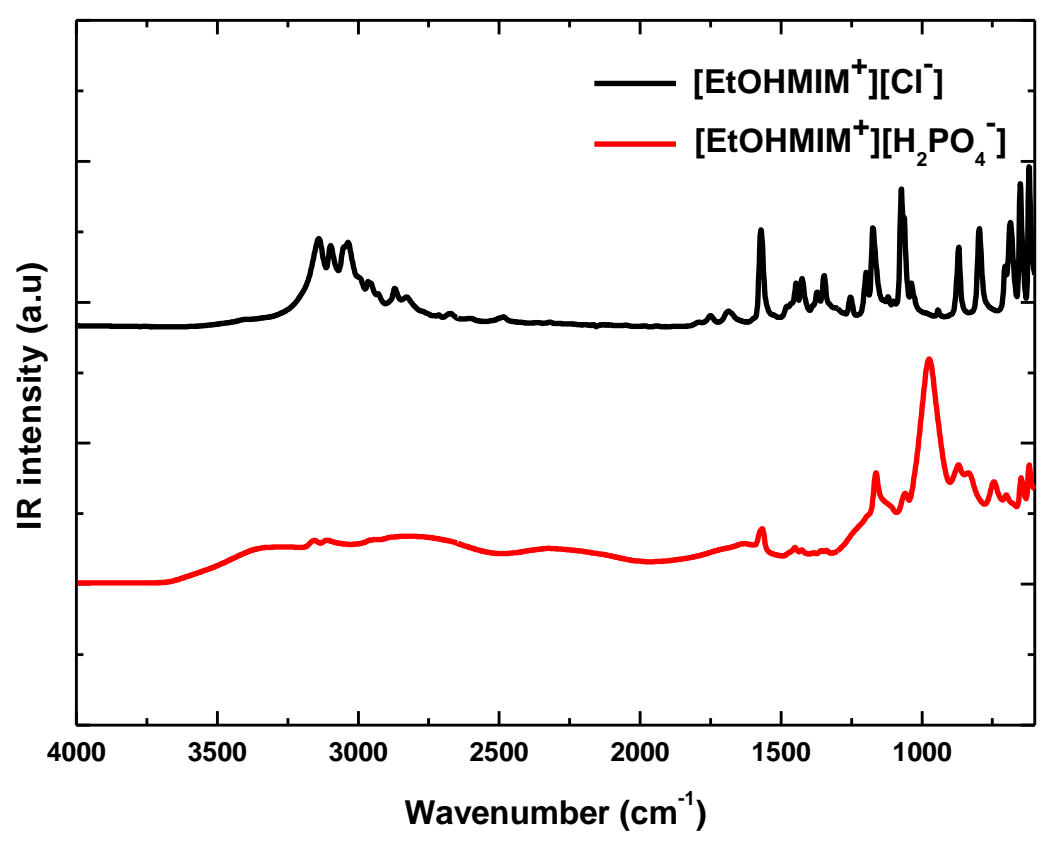

Figure.3. FTIR/ATR spectra of $\left[\mathrm{EtOHMIM}^{+}\right]\left[\mathrm{Cl}^{-}\right]$and $\left[\mathrm{EtOHMIM}^{+}\right]\left[\mathrm{H}_{2} \mathrm{PO}_{4}{ }^{-}\right]$in the spectral range $4000-600$ $\mathrm{cm}^{-1}$. 
Table 1: Observed FTIR/ATR bands and their assignment of 1-(hydroxyethyl)-3-methylimidazolium with chloride and dihydrogenophosphate anions $(\mathrm{vw}=$ very weak, $\mathrm{w}=$ weak, $\mathrm{m}=$ medium, $\mathrm{s}=$ strong, $\mathrm{sh}=$ shoulder, $\operatorname{str}=$ stretch, $\mathrm{d}=$ deformation, bend = bending deformation, $\omega=$ wagging, $\rho=$ rocking, $\mathrm{s}=$ symmetric, as = antisymmetric).

\section{[EtOHMIM $\left.^{+}\right]$}

[EtOHMIM+

\begin{tabular}{ll}
{$\left[\mathrm{Cl}^{-}\right]$} & {$\left[\mathbf{H}_{2} \mathbf{P O}_{4}{ }^{-}\right]$} \\
\hline $621(\mathrm{~s})$ & $619(\mathrm{w})$ \\
$652(\mathrm{~s})$ & $648(\mathrm{w})$ \\
$687(\mathrm{~s})$ & \\
$706(\mathrm{~m})$ & $702(\mathrm{vw})$ \\
& $746(\mathrm{w})$ \\
$797(\mathrm{~s})$ & \\
& $831(\mathrm{sh})$ \\
$870(\mathrm{~s})$ & $870(\mathrm{w})$ \\
$943(\mathrm{vw})$ & \\
& $974(\mathrm{~s})$ \\
$1037(\mathrm{~m})$ & \\
$1063(\mathrm{sh})$ & $1060(\mathrm{w})$
\end{tabular}

1074 (s)

1100 (vw)

1120 (vw)

$1175(\mathrm{~m})$

1198 (m)

$1254(\mathrm{w})$

$1338(\mathrm{vw})$

$1347(\mathrm{~m}) \quad 1360(\mathrm{vw})$

1371 (w)

$1387(\mathrm{sh}) \quad 1387(\mathrm{vw})$

$1425(\mathrm{~m}) \quad 1427(\mathrm{vw})$

$1447(\mathrm{~m}) \quad 1450(\mathrm{w})$

1464 (sh)

1479 (w)

1572 (s)

1687 (w)

1751 (w)

2486 (vw)

2600 (vw)

2673 (vw)

1630 (sh)
Assignment

Refs

$\omega(\mathrm{N}-\mathrm{H}), v \mathrm{C}=\mathrm{C}, \mathrm{CH}_{3}(\mathrm{~N}) \mathrm{CN}$ str, $\tau \mathrm{CH}($ imidazolium)

$\omega(\mathrm{N}-\mathrm{H}), \mathrm{CH}_{2}(\mathrm{~N})$ str, $\mathrm{CH}_{3}(\mathrm{~N}) \mathrm{CN}$ str, $v \mathrm{~N}-\mathrm{CH}_{3}, \gamma(\mathrm{N}-\mathrm{C})$

$\omega(\mathrm{C}-\mathrm{H}), \delta \mathrm{CC}$

$\mathrm{CH}_{2}(\mathrm{~N}), \mathrm{CH}_{3}(\mathrm{~N}) \mathrm{CN}$ str

$\omega(\mathrm{C}-\mathrm{H})$, ring $\mathrm{HCCH}$ sym bend, $\mathrm{CH}_{3}(\mathrm{~N})$ bend, $\mathrm{CH}_{2}(\mathrm{~N})$ bend

ring $\mathrm{HCCH}$ asym bend, $\mathrm{CS}$ str

ring $\mathrm{HCCH}$ asym bend, $\mathrm{NC}(\mathrm{H}) \mathrm{N}$ bend, $\gamma(\mathrm{C}-\mathrm{H})$

$\rho_{\text {as }}\left(\mathrm{CH}_{2}\right), \mathrm{NC}(\mathrm{H}) \mathrm{N}$ bend, $\mathrm{P}-\mathrm{OH}$ str, $v_{1}\left(\mathrm{PO}_{4}\right)$

$\rho_{\text {as }}\left(\mathrm{CH}_{2}\right)$

(P-O) stretch, $v_{3}\left(\mathrm{PO}_{4}\right)$

ring sym str, $\mathrm{CH}_{3}(\mathrm{~N})$ str, $\mathrm{CH}_{2}(\mathrm{~N})$ str, vC-C

Ring ip asym str, $\mathrm{CC}$ str, $\mathrm{CH}_{3}(\mathrm{~N})$ twist, $\mathrm{SNS}$ asym str, $v(\mathrm{C}-\mathrm{O})$,

$\mathrm{P}-\mathrm{O}$ str, $v_{3}\left(\mathrm{PO}_{4}\right)$

Ring ip asym str, $\mathrm{CC}$ str, $\mathrm{CH}_{3}(\mathrm{~N})$ twist, SNS asym str

$\mathrm{CC}$ str, $v$ (C-C)

$\delta \mathrm{CH}$, ring $\mathrm{HCCH}$ sym bend, $\mathrm{CC}$ str, $\rho\left(\mathrm{CH}_{3}\right)$

ring asym str $\mathrm{CH}_{2}(\mathrm{~N}), \mathrm{CH}_{3}(\mathrm{~N}) \mathrm{CN}$ str, $\mathrm{CCstr}, v \mathrm{~N}-\mathrm{C}$

ring s $\mathrm{CH}_{2}(\mathrm{~N}), \mathrm{CH}_{3}(\mathrm{~N}) \mathrm{CN}$ str, $v(\mathrm{C}-\mathrm{C}), \omega(\mathrm{C}-\mathrm{H}, \tau(\mathrm{C}-\mathrm{H})$

$\rho \mathrm{CH}$ (imidazolium)

Imidazolium ring: $\mathrm{C}-\mathrm{N}, \mathrm{C}=\mathrm{N}$ str, $\mathrm{CC}$ str, $\mathrm{CH}_{2}(\mathrm{~N})$ str, $\mathrm{CH}_{3}(\mathrm{~N}), v$

(C-C), $\mathrm{P}=\mathrm{O}$ str

Imidazolium ring: $\mathrm{C}-\mathrm{N}, \mathrm{C}=\mathrm{N}$ str, $\mathrm{CH}_{2}(\mathrm{~N})$ str, $\mathrm{CH}_{3}(\mathrm{~N}) \mathrm{CN}$ str, $v$ $(\mathrm{C}-\mathrm{C}), \omega\left(\mathrm{C}-\mathrm{H}_{2}\right)$

$\delta(\mathrm{CH}), \delta_{\mathrm{s}}\left(\mathrm{CH}_{3}\right)$

$[21,26,27,28]$

$[21,26,29,30]$

$[21,28,31]$

$[18,21,22]$

$[21,25,26,27]$

$[21,23,24]$

$[29,32]$

$[21,26,32,33]$

$[21,34,35]$

$[33,36]$

$[21,37]$

$[21,26,33]$

$[21,26,38]$

$[21,28]$

$[21,26,29]$

$[26,28,29]$

$[21,26,39]$

[30]

$[21,26,36]$

$[21,26,29,40]$

[21]

$\rho\left(\mathrm{CH}_{2}\right), \rho(\mathrm{CH}), \delta\left(\mathrm{CH}_{2}\right)$ [op], $\omega(\mathrm{CH})$, ring ip asym str, $\mathrm{CH}_{2}(\mathrm{~N})$

bend, $\mathrm{CC}$ str, $\mathrm{CH}_{2}(\mathrm{~N})$ str, $\mathrm{CH}_{3}(\mathrm{~N}) \mathrm{CN}$ str, $\rho(\mathrm{N}-\mathrm{H})$

$[21,26,28]$

Imidazoliumring:C-N, $\quad \mathrm{C}=\mathrm{N} \quad$ strband, $\delta \mathrm{s}\left(\mathrm{CH}_{2}\right), \quad \mathrm{C}-\mathrm{H}$ deformation, $\rho(\mathrm{N}-\mathrm{H})$

$[21,26,28]$

$\delta\left(\mathrm{CH}_{2}\right), \mathrm{CCH} \mathrm{HCH}$ as bend,ring ip asym str, $\mathrm{CH}_{3}(\mathrm{~N})$ $\operatorname{str}, \delta_{\mathrm{a}}\left(\mathrm{CH}_{3}\right)$

$\delta_{\mathrm{a}}\left(\mathrm{CH}_{3}\right), \delta\left(\mathrm{CH}_{2}\right), \mathrm{CH}_{3}(\mathrm{~N}) \mathrm{HCH}$ sym bend, $\mathrm{CH}_{3}(\mathrm{~N}) \mathrm{CN}$ str

$[21,26,29]$

$\delta\left(\mathrm{CH}_{2}\right), \mathrm{CCH} \mathrm{HCH}$ as bend

$[21,29,40]$

$[21,26]$

Imidazolium ring $v(\mathrm{~N}=\mathrm{C})$, ring ip sym/asym str, $\mathrm{CH}_{2}(\mathrm{~N})$,

$[21,26,28]$

$\mathrm{CH}_{3}(\mathrm{~N}) \mathrm{CN}$ str

$v(\mathrm{C}=\mathrm{C})$

[25]

$v(\mathrm{C}=\mathrm{C})$, ring $\mathrm{C}=\mathrm{C}, \mathrm{N}=\mathrm{C}-\mathrm{N}$ str

$[21,25]$

overtone $=\mathrm{C}-\mathrm{H}$ str

[21]

$v(\mathrm{C}=\mathrm{C})$

[21]

$v_{\mathrm{s}}\left(\mathrm{CH}_{2}\right)$

[21]

$v_{\mathrm{s}}\left(\mathrm{CH}_{2}\right)$ 


\begin{tabular}{|c|c|c|c|}
\hline $2714(\mathrm{vw})$ & & $v_{\mathrm{s}}\left(\mathrm{CH}_{2}\right)$ & {$[21]$} \\
\hline $2830(w)$ & $2823(\mathrm{sh})$ & $v_{\mathrm{s}}\left(\mathrm{CH}_{2}\right)$ & {$[21]$} \\
\hline $2870(w)$ & & $v_{\text {as }}\left(\mathrm{CH}_{2}\right)$ & {$[21,29]$} \\
\hline $2928(w)$ & & $v_{\text {as }}\left(\mathrm{CH}_{2}\right)$ & {$[21,29]$} \\
\hline $2954(\mathrm{~m})$ & & $v_{\mathrm{s}}\left(\mathrm{CH}_{2}\right), \mathrm{CH}_{3}(\mathrm{~N}), \mathrm{HCH}$ as str & {$[21,29]$} \\
\hline $2966(\mathrm{~m})$ & $2958(\mathrm{sh})$ & $\mathrm{CH}_{3}(\mathrm{~N})$ asym str, $\mathrm{CH}_{2} \mathrm{HCH}$ asym str, $v_{\mathrm{s}}\left(\mathrm{CH}_{2}\right)$ & {$[21,26,29]$} \\
\hline $2993(\mathrm{sh})$ & & $v_{\text {as }}\left(\mathrm{CH}_{2}\right), \mathrm{CH}_{3}(\mathrm{~N}) \mathrm{HCH}$ asym str, $v(\mathrm{C}-\mathrm{H})$ & {$[21,29.41]$} \\
\hline $3035(\mathrm{~m})$ & & $v(\mathrm{C}-\mathrm{H})$ & {$[21.41]$} \\
\hline $3051(\mathrm{sh})$ & & $v_{\text {as }}\left(\mathrm{CH}_{3}\right), v(\mathrm{C}-\mathrm{H})$ & {$[21,29.41]$} \\
\hline $3097(\mathrm{~m})$ & & $v(\mathrm{C}-\mathrm{H}),=\mathrm{C}-\mathrm{H}$ Str & {$[21,26,29,40.41]$} \\
\hline & $3111(w)$ & $\mathrm{H}-\mathrm{C}-\mathrm{C}-\mathrm{H}$ asym str, $\mathrm{CH}_{3}(\mathrm{~N}), v(\mathrm{C}-\mathrm{H}),=\mathrm{C}-\mathrm{H}$ str & {$[21,26,28,29.41]$} \\
\hline $3140(\mathrm{~m})$ & & $\mathrm{H}-\mathrm{C}-\mathrm{C}-\mathrm{H}$ asym str, $v(\mathrm{C}-\mathrm{H}),=\mathrm{C}-\mathrm{H}$ str & {$[21,26,29.41]$} \\
\hline & $3157(w)$ & $\mathrm{H}-\mathrm{C}-\mathrm{C}-\mathrm{H}$ asym str, $v_{\text {as }}(\mathrm{C}-\mathrm{H}), \mathrm{CH}_{3}(\mathrm{~N}),=\mathrm{C}-\mathrm{H}$ str & {$[21,26,29,40.41]$} \\
\hline & 3311(sh) & $v(\mathrm{O}-\mathrm{H})$ & [42] \\
\hline
\end{tabular}

\subsubsection{Region $1300-600 \mathrm{~cm}^{-1}$}

For the $\mathrm{Cl}^{-}$anion, this spectral zone (Figure.4) is more intense than for $\left[\right.$EtOHMIM$\left.{ }^{+}\right]\left[\mathrm{H}_{2} \mathrm{PO}_{4}{ }^{-}\right]$. Conversely we notice new strong intense peak in $974 \mathrm{~cm}^{-1}$ which is assigned to the symmetric stretching $v_{3}$ mode of dihydrogenophosphate anion not available for $\left[\mathrm{EtOHMIM}^{+}\right]\left[\mathrm{Cl}^{-}\right]$. The presence of this new intense is assigned to (P-O) stretching mode[33,36]. The modes at 619, 648 and $706 \mathrm{~cm}^{-1}$ are assigned to $(\mathrm{N}-\mathrm{H})$ wagging and $\mathrm{CH}_{3}(\mathrm{~N}) \mathrm{CN}$ stretching. The band due to $\left(\mathrm{CH}_{2}\right)$ rocking antisymmetric of the cation $\left[\mathrm{EtOHMIM}^{+}\right]$and $\mathrm{NC}(\mathrm{H}) \mathrm{N}$ bending occurs at $870 \mathrm{~cm}^{-1}$ for the two ILs and is of weak to strong intensity. Also this band can be assigned to (P-OH) stretching mode of $\mathrm{H}_{2} \mathrm{PO}_{4}^{-}$anion [21,26,32,33].For $\left[\mathrm{EtOHMIM}^{+}\right]\left[\mathrm{H}_{2} \mathrm{PO}_{4}{ }^{-}\right]$we observe two modes in 746 and $831 \mathrm{~cm}^{-1}$ assigned to ring $\mathrm{HCCH}$ bending while for $\left[\mathrm{EtOHMIM}^{+}\right]\left[\mathrm{Cl}^{-}\right]$the ring $\mathrm{HCCH}$ bending was observed at $797 \mathrm{~cm}^{-1}$.In $1074 \mathrm{~cm}^{-1}$ a strong peak assigned to $\mathrm{CH}_{3}(\mathrm{~N})$ twistingof $\left[\mathrm{EtOHMIM}{ }^{+}\right]\left[\mathrm{Cl}^{-}\right]$with weak intensity at1060 $\mathrm{cm}^{-1}$ of $\left[\right.$ EtOHMIM$\left.{ }^{+}\right]\left[\mathrm{H}_{2} \mathrm{PO}_{4}^{-}\right]$. The modes at 1175 and $1198 \mathrm{~cm}^{-1}$ of $\left[\mathrm{EtOHMIM}^{+}\right]\left[\mathrm{Cl}^{-}\right]$are assigned to $\mathrm{CH}_{3}(\mathrm{~N}) \mathrm{CN}$ stretchingwhich is observed at 1163 $\mathrm{cm}^{-1}$ for $\left[\mathrm{EtOHMIM}^{+}\right]\left[\mathrm{H}_{2} \mathrm{PO}_{4}^{-}\right]$. The peak of $\left[\mathrm{EtOHMIM}^{+}\right]\left[\mathrm{Cl}^{-}\right]$centered at $1254 \mathrm{~cm}^{-1}$ is assigned to $(\mathrm{C}-\mathrm{H})$ rocking mode of imidazolium[27]. 


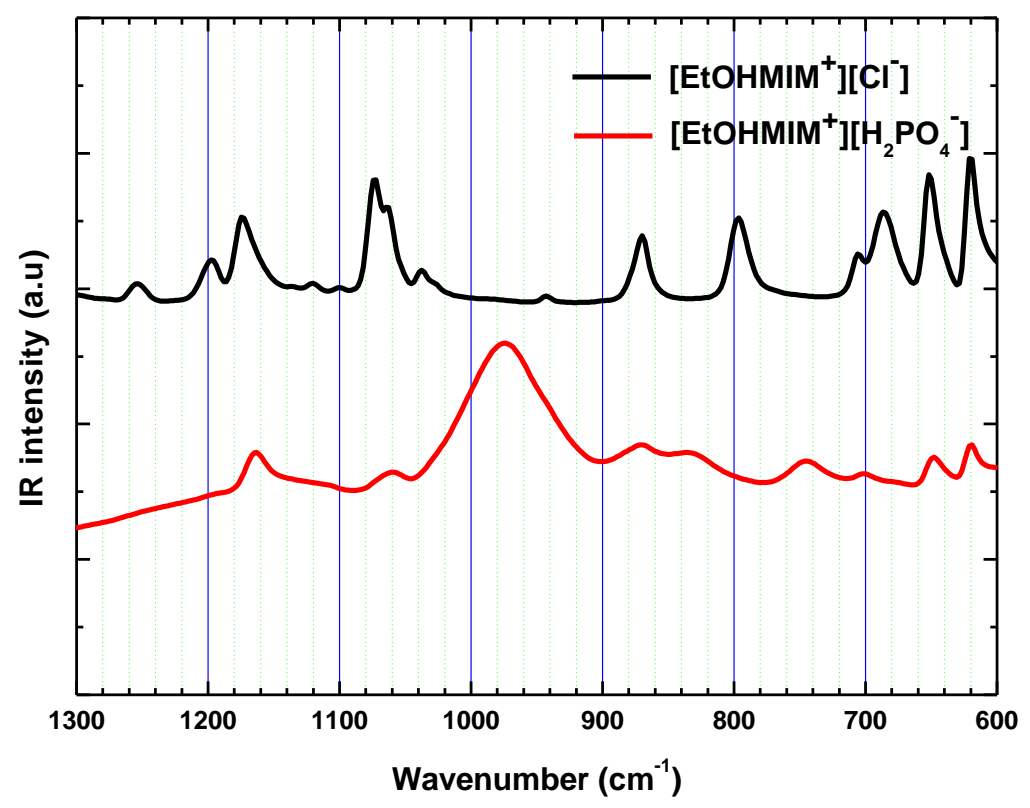

Figure.4. FTIR/ATR spectra of $\left[\mathrm{EtOHMIM}^{+}\right]\left[\mathrm{Cl}^{-}\right]$and $\left[\mathrm{EtOHMIM}^{+}\right]\left[\mathrm{H}_{2} \mathrm{PO}_{4}{ }^{-}\right]$in the spectral range $1300-$ $600 \mathrm{~cm}^{-1}$.

\subsubsection{Region $1800-1300 \mathrm{~cm}^{-1}$}

In this spectral zone (Figure.5) we observe a spectrum with high density for the $\mathrm{Cl}^{-}$anion than for the $\mathrm{H}_{2} \mathrm{PO}_{4}{ }^{-}$ anion. We notice the mode in $1347 \mathrm{~cm}^{-1}$ for the $\mathrm{Cl}^{-}$anion which is transformed for the $\mathrm{H}_{2} \mathrm{PO}_{4}{ }^{-}$anion to 1360 and $1338 \mathrm{~cm}^{-1}$ modes (Imidazolium ring: $\mathrm{C}-\mathrm{N}, \mathrm{C}=\mathrm{N}$ str, $\mathrm{CH}_{2}(\mathrm{~N})$ str, $\mathrm{CH}_{3}(\mathrm{~N}) \mathrm{CN}$ Str, $v(\mathrm{C}-\mathrm{C})$ ) $[21,26,29,40]$.We also observe in $1338 \mathrm{~cm}^{-1}$ the presence of the stretching mode $\mathrm{P}=\mathrm{O}$ for $\mathrm{H}_{2} \mathrm{PO}_{4}{ }^{-}$anion [36].The spectral zone of the $\mathrm{CH}_{2}$ rockingof the cation [EtOHMIM ${ }^{+}$]1500-1400also seems to be influenced by the choice of the anion in a less important way. In the spectral zone $1800-1500 \mathrm{~cm}^{-1}$, we observe a shift in frequency of the vibrational mode attributed to the ring $\mathrm{C}=\mathrm{C}$ and $=\mathrm{C}-\mathrm{H}$ stretching $[21,32]$. The shift is from $1572 \mathrm{~cm}^{-1}$ for the anion $\mathrm{Cl}^{-}$to a shoulder at $1566 \mathrm{~cm}^{-1}$ for $\mathrm{H}_{2} \mathrm{PO}_{4}$ and conversely from $1630 \mathrm{~cm}^{-1}$ for $\mathrm{H}_{2} \mathrm{PO}_{4}^{-}$ to an doublet in 1687 and $1751 \mathrm{~cm}^{-1}$ for the $\mathrm{Cl}^{-}$anion. 


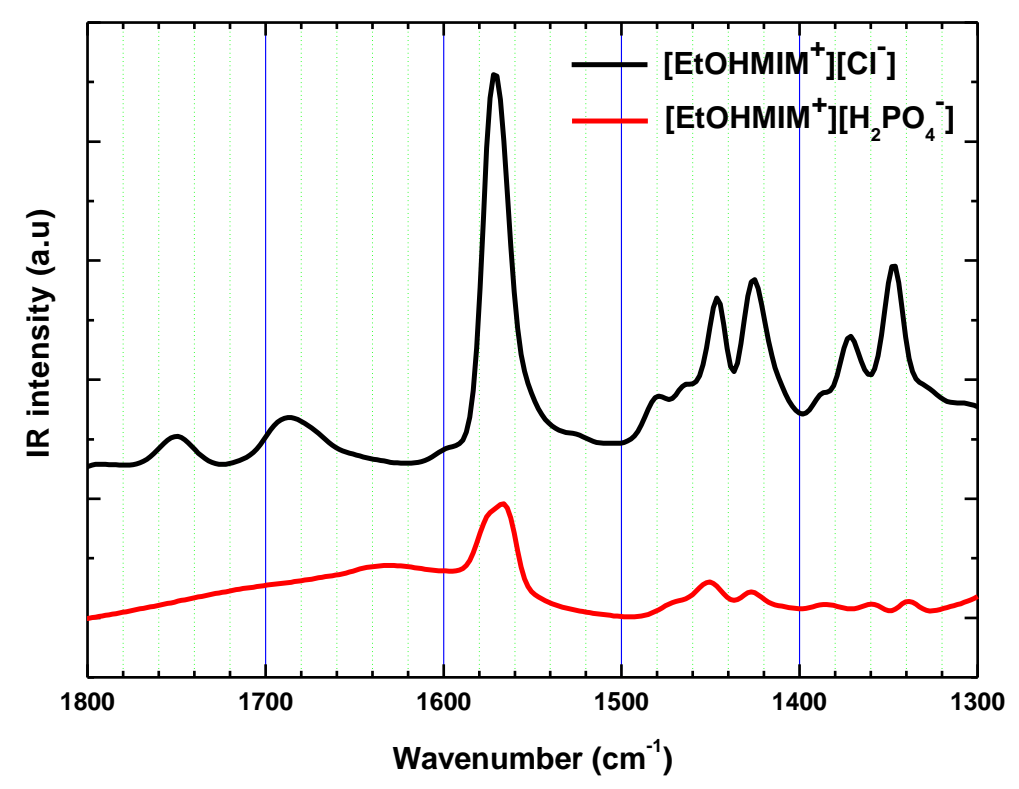

Figure.5. FTIR/ATR spectra of $\left[\mathrm{EtOHMIM}^{+}\right]\left[\mathrm{Cl}^{-}\right]$and $\left[\mathrm{EtOHMIM}^{+}\right]\left[\mathrm{H}_{2} \mathrm{PO}_{4}^{-}\right]$in the spectral range $1800-$

$$
1300 \mathrm{~cm}^{-1} \text {. }
$$

\subsubsection{Region $3500-2400 \mathrm{~cm}^{-1}$}

In this spectral region (Figure.6), we observe more peaks for the $\mathrm{Cl}^{-}$anion than for the $\mathrm{H}_{2} \mathrm{PO}_{4}{ }^{-}$anion. In the spectral range $3000-2600 \mathrm{~cm}^{-1}$, we observe the vibrational mode attributed to the symmetric and antisymmetric $\left(\mathrm{CH}_{2}\right)$ of the cation [EtOHMIM $\left.{ }^{+}\right][21,29]$. The $\mathrm{C}-\mathrm{H}$ ring stretching occurs in the regions 3100$3000 \mathrm{~cm}^{-1}$ which is the characteristic region of the ready identification of the $\mathrm{C}-\mathrm{H}$ stretching vibrations [41].The vibrational mode of the $(\mathrm{C}-\mathrm{H})$ is observed in the spectral range: 2993, 3035, 3051, $3097 \mathrm{~cm}^{-1}$ and $3140 \mathrm{~cm}^{-1}$ for the anion $\mathrm{Cl}^{-}$and at 3111 and $3157 \mathrm{~cm}^{-1}$ for the anion $\mathrm{H}_{2} \mathrm{PO}_{4}^{-}$. We notice the mode in $3140 \mathrm{~cm}^{-1}$ for the $\mathrm{Cl}^{-}$anion which is transformed for the $\mathrm{H}_{2} \mathrm{PO}_{4}{ }^{-}$anion to 3111 and $3157 \mathrm{~cm}^{-1}$ modes (H-C-C-H asym str, $v_{\text {as }}(\mathrm{C}-\mathrm{H}), \mathrm{CH}_{3}(\mathrm{~N}),=\mathrm{C}-\mathrm{H}$ stretching $)[21,26,29,40,41]$.Note that the presence of a shoulder intensity predicted at $3311 \mathrm{~cm}^{-1}$ can be assigned to the corresponding vibrational mode $\mathrm{OH}$ (alcohol function of the cation) and possibly $\mathrm{OH}$ of $\mathrm{H}_{2} \mathrm{PO}_{4}^{-}$anion [42]. 


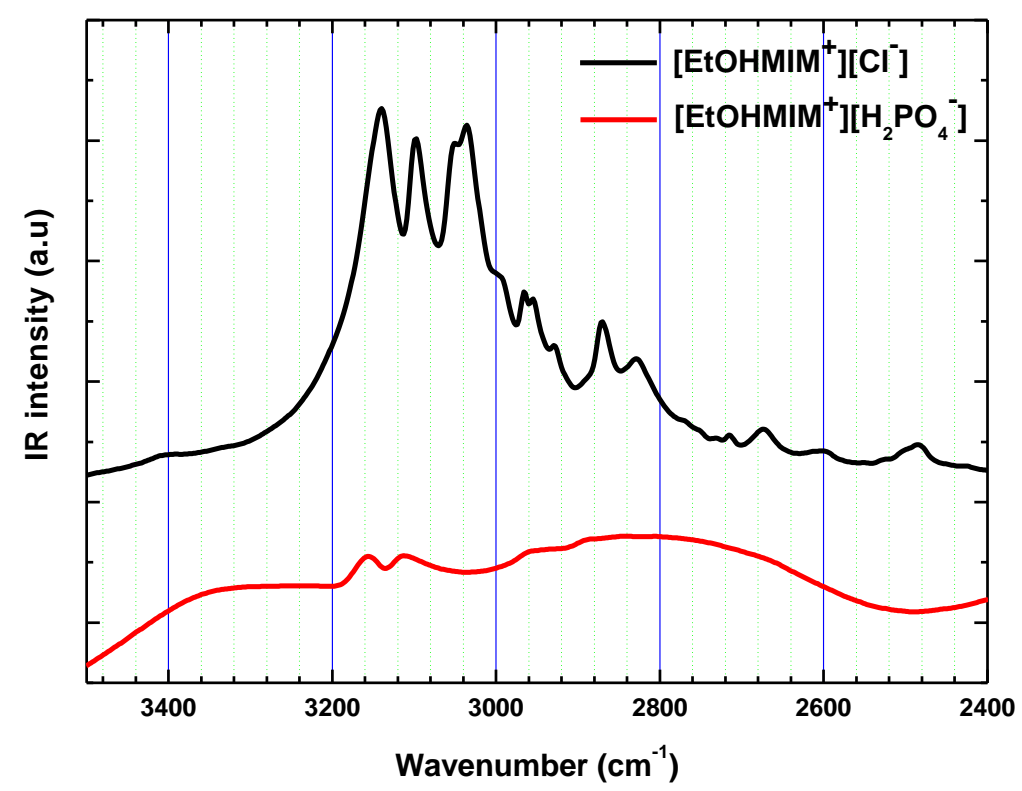

Figure.6. FTIR/ATR spectra of $\left[\mathrm{EtOHMIM}^{+}\right]\left[\mathrm{Cl}^{-}\right]$and $\left[\mathrm{EtOHMIM}^{+}\right]\left[\mathrm{H}_{2} \mathrm{PO}_{4}{ }^{-}\right]$in the spectral range $3500-$

$$
2400 \mathrm{~cm}^{-1}
$$

3.2.5 The comparison between Raman spectra of ionic liquids: 1-(hydroxyethyl)-3-methylimidazolium chloride [EtOHMIM $\left.{ }^{+}\right]\left[\mathrm{Cl}^{-}\right]$and 1-(hydroxyethyl)-3-methylimidazolium dihydrogenophosphate $\left[\mathrm{EtOHMIM}^{+}\right]\left[\mathrm{H}_{2} \mathrm{PO}_{4}^{-}\right]$.

FT-Raman spectra [3500-45 $\mathrm{cm}^{-1}$ ] of the two ILs are illustrated in Figure.7. The observed Raman bands and their detailed assignments are listed in Table 2. We distinguish three well defined spectral regions: 3500$2700,1700-1000$ and $1000-45 \mathrm{~cm}^{-1}$. 


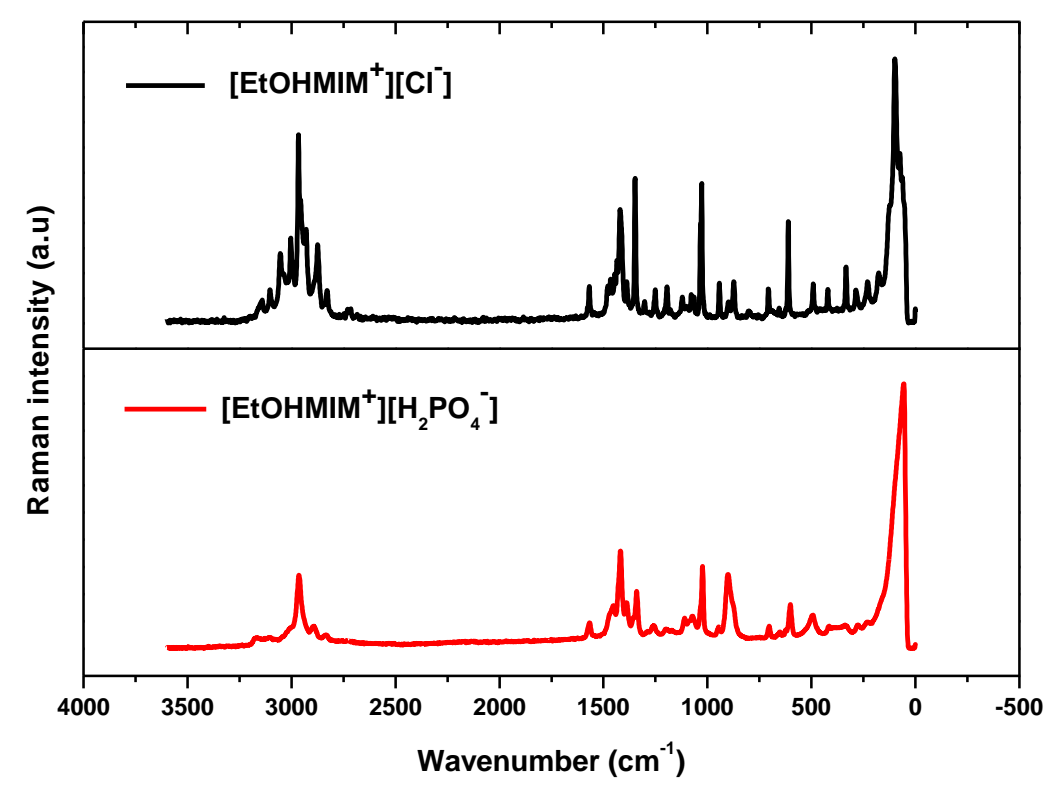

Figure.7. Raman spectra of $\left[\mathrm{EtOHMIM}^{+}\right]\left[\mathrm{Cl}^{-}\right]$and $\left[\mathrm{EtOHMIM}^{+}\right]\left[\mathrm{H}_{2} \mathrm{PO}_{4}^{-}\right]$in the spectral range $3500-45 \mathrm{~cm}^{-1}$.

\section{Table 2}

Observed FT-Raman bands and their assignment of 1-(hydroxyethyl)-3-methylimidazoliumwith chloride and dihydrogenophosphateanions $(\mathrm{vw}=$ very weak, $\mathrm{w}=$ weak, $\mathrm{m}=$ medium, $\mathrm{s}=$ strong, $\mathrm{sh}=$ shoulder, $\mathrm{str}=$ stretch, $d=$ deformation, bend $=$ bending deformation, $\omega=$ wagging, $\rho=$ rocking, $\tau=$ torsions $=$ symmetric, as $=$ antisymmetric) .

$\left[\right.$ EtOHMIM $\left.^{+}\right]$

Assignment

Refs

\begin{tabular}{|c|c|c|c|}
\hline$\left[\mathrm{Cl}^{-}\right]$ & {$\left[\mathrm{H}_{2} \mathrm{PO}_{4}{ }^{-}\right]$} & & \\
\hline 63(sh) & $56(s)$ & Intermolecular vibration & {$[18,22]$} \\
\hline $75(\mathrm{sh})$ & & Intermolecular vibration & {$[18,22]$} \\
\hline $99(\mathrm{~s})$ & & Intermolecular vibration & {$[18,22]$} \\
\hline $124(\mathrm{sh})$ & & Intermolecular vibration & {$[18,22]$} \\
\hline $177(w)$ & & Intermolecular vibration, $\omega(\mathrm{N}-\mathrm{C}), \tau(\mathrm{N}-\mathrm{C}), \rho\left(\mathrm{CH}_{2}\right)$ & {$[18,22,35]$} \\
\hline $230(w)$ & $230(\mathrm{vw})$ & $\rho\left(\mathrm{CH}_{2}\right), \gamma \mathrm{N}-\mathrm{CH}_{3}$ & {$[25,26,27]$} \\
\hline $286(w)$ & $276(\mathrm{vw})$ & $\mathrm{NCH}_{3},(\mathrm{~N}) \mathrm{CH}_{2} \mathrm{CN}$ bend, $\rho\left(\mathrm{CH}_{2}\right), \mathrm{CN}$ stretch & {$[26,43]$} \\
\hline $334(w)$ & $335(\mathrm{vw})$ & $\delta \mathrm{NCH}_{3}$ & {$[18,26]$} \\
\hline 421(w) & 417(vw) & $(\mathrm{N}) \mathrm{CH}_{2}$ str, $\mathrm{NCH}_{3}, v_{2}\left(\mathrm{PO}_{4}\right), \mathrm{P}-\mathrm{O}$ bend & {$[18,26,33]$} \\
\hline 491(w) & 494(w) & $\rho(\mathrm{CH}), \tau\left(\mathrm{CH}_{3}\right), v_{4}\left(\mathrm{PO}_{4}\right)$ & {$[22,27,33]$} \\
\hline $611(\mathrm{~m})$ & $601(w)$ & $\omega(\mathrm{N}-\mathrm{C}), \mathrm{NCH}_{3}, \mathrm{CN}$ stretch, $\mathrm{P}-\mathrm{O}$ bend & {$[23,33,44]$} \\
\hline $655(\mathrm{vw})$ & & $\delta \mathrm{CC}, \mathrm{C}=\mathrm{C}-\mathrm{H},(\mathrm{N}) \mathrm{CH}_{2}, \mathrm{NCH}_{3}, \mathrm{CN}$ stretch & {$[24,25,26]$} \\
\hline 707(w) & $705(\mathrm{vw})$ & $\mathrm{C}=\mathrm{C}-\mathrm{H}, \mathrm{H}-\mathrm{C}-\mathrm{C}-\mathrm{H}, \mathrm{PO}_{2}$ sym str & {$[25,26,36]$} \\
\hline
\end{tabular}




\begin{tabular}{|c|c|c|c|}
\hline $873(w)$ & $875(\mathrm{sh})$ & $\rho\left(\mathrm{CH}_{2}\right), \mathrm{NC}(\mathrm{H}) \mathrm{N}$ bend, $\mathrm{CCH}$ bend, $v_{1}\left(\mathrm{PO}_{4}\right), \mathrm{POH}$ sym str & {$[26,33,45]$} \\
\hline 899(vw) & $901(\mathrm{~m})$ & $\mathrm{CH}$ def vib $[\mathrm{op}], v_{1}\left(\mathrm{PO}_{4}\right), \mathrm{P}-\mathrm{OH}$ str & {$[30,31,33]$} \\
\hline $942(w)$ & $945(\mathrm{vw})$ & $\mathrm{CC}$ str,POH asym stretch, & {$[45,46]$} \\
\hline $1027(\mathrm{~m})$ & $1023(\mathrm{~m})$ & $v(\mathrm{C}-\mathrm{C}), \delta \mathrm{CC}, \delta \mathrm{CH}, v \mathrm{NCH}_{3}$ & {$[26,47,48]$} \\
\hline $1065(w)$ & 1072(vw) & vs $(\mathrm{C}-\mathrm{C}), \mathrm{PO}_{2}$ sym stretch, $\mathrm{P}-\mathrm{O}$ stretch, $v_{3}\left(\mathrm{PO}_{4}\right)$ & {$[18,33,40,45,49]$} \\
\hline $1078(w)$ & & $v \mathrm{~s}(\mathrm{C}-\mathrm{C})$ & {$[18,40]$} \\
\hline $1121(w)$ & $1110(\mathrm{vw})$ & ring $\mathrm{H}-\mathrm{C}-\mathrm{C}-\mathrm{H}$ symbend, ring ip asym str, $\rho\left(\mathrm{CH}_{3}\right)$ & {$[29,38,43]$} \\
\hline 1194(w) & 1194(vw) & $\rho\left(\mathrm{CH}_{2}\right), \mathrm{PO}_{2}$ sym stretch & {$[36,47]$} \\
\hline $1251(w)$ & $1257(\mathrm{vw})$ & $v(\mathrm{C}-\mathrm{C}), v \mathrm{NC}, \delta \mathrm{NCH}, \rho \mathrm{CH}_{2}$ & {$[27,29,37]$} \\
\hline $1303(w)$ & & $v(\mathrm{C}-\mathrm{C}), \delta \mathrm{CCH}, \mathrm{t}\left(\mathrm{CH}_{2}\right)[\mathrm{op}], \gamma(\mathrm{CH}), \mathrm{CN}$ ring & {$[27,29,30,31]$} \\
\hline $1347(\mathrm{~m})$ & $1340(w)$ & $\mathrm{NCH}_{3},(\mathrm{~N}) \mathrm{CH}_{2} \mathrm{CN}$ str, Ring ip sym str, $\mathrm{P}=\mathrm{O}$ sym stretch & {$[18,36,43,44]$} \\
\hline & $1356(\mathrm{vw})$ & $\mathrm{NCH}_{3},(\mathrm{~N}) \mathrm{CH}_{2} \mathrm{CN}$ str, Ring ip sym str & {$[18,43]$} \\
\hline $1389(w)$ & $1389(w)$ & Imidazolium ring: $\mathrm{C}-\mathrm{N}, \mathrm{C}=\mathrm{N}$ stretch band & {$[18,26]$} \\
\hline $1420(\mathrm{~m})$ & 1418(m) & $\begin{array}{l}\text { Imidazolium ring: } \mathrm{C}-\mathrm{N}, \mathrm{C}=\mathrm{N} \text { stretch band, }(\mathrm{N}) \mathrm{CH}_{2} \mathrm{str}, \mathrm{C}-\mathrm{H} \\
\text { deformation, }\end{array}$ & {$[25,26]$} \\
\hline $1435(w)$ & & $\begin{array}{l}\text { Imidazolium ring: } \mathrm{C}-\mathrm{N}, \mathrm{C}=\mathrm{N} \text { stretch band, } \delta \mathrm{CH}_{2} \text {, ring ip asym } \\
\text { str, } \mathrm{CC} \text { str, }(\mathrm{N}) \mathrm{CH}_{2} \mathrm{str}, \mathrm{NCH}_{3} \mathrm{CN} \text { str }\end{array}$ & {$[25,26]$} \\
\hline $1445(w)$ & $1453(w)$ & $v(\mathrm{C}-\mathrm{C}), v \mathrm{CH}_{3}-\mathrm{N}-\mathrm{CN}$ & {$[39,40]$} \\
\hline $1466(w)$ & & $\mathrm{NCH}_{3} \mathrm{HCH}$ sym bend, $\mathrm{NCH}_{3} \mathrm{CNstr}, \delta \mathrm{HCC}, v(\mathrm{C}-\mathrm{C})$ & {$[37,38,39,40]$} \\
\hline $1480(w)$ & & $\delta \mathrm{CH}_{3}, v \mathrm{CN}, \delta \mathrm{NCH}$ & {$[39,40]$} \\
\hline $1568(w)$ & $1567(\mathrm{vw})$ & $v(\mathrm{C}-\mathrm{C}), v(\mathrm{~N}-\mathrm{C})$ & [47] \\
\hline $2829(w)$ & 2835(vw) & $v \mathrm{~s}\left(\mathrm{CH}_{3}\right),(\mathrm{N}) \mathrm{CH}_{2}, \mathrm{NCH}_{3}$ sym stretch & {$[25,26,44]$} \\
\hline 2874(w) & 2893(vw) & $v \mathrm{~s}\left(\mathrm{CH}_{2}\right),(\mathrm{N}) \mathrm{CH}_{2}, \mathrm{NCH}_{3}$ sym stretch & {$[25,26,29]$} \\
\hline $2930(w)$ & & $(\mathrm{N}) \mathrm{CH}_{2}, \mathrm{NCH}_{3}$ sym stretch & {$[25,26]$} \\
\hline 2957(sh) & & vs $\left(\mathrm{CH}_{3}\right), \mathrm{NCH}_{3}$ sym stretch & {$[25,47]$} \\
\hline $2966(\mathrm{~m})$ & 2964(m) & $\mathrm{NCH}_{3}$ asym stretch, $v_{\text {as }}\left(\mathrm{CH}_{3}\right)$ & {$[25,26,29]$} \\
\hline 3003(w) & 3003(vw) & $\mathrm{NCH}_{3}$ asym stretch, C-H stretch & {$[25,26]$} \\
\hline $3037(\mathrm{sh})$ & & C-H stretch & {$[25,26]$} \\
\hline $3054(w)$ & & $\mathrm{C}-\mathrm{H}$ stretch & {$[25,26,37]$} \\
\hline $3104(w)$ & $3105(\mathrm{vw})$ & $\mathrm{H}-\mathrm{C}-\mathrm{C}-\mathrm{H}$ asym stretch, $v_{\mathrm{as}}(\mathrm{H}-\mathrm{C}(2)),(\mathrm{N}) \mathrm{CH}_{2}$ & {$[25,26,29]$} \\
\hline 3143(vw) & & $\mathrm{H}-\mathrm{C}-\mathrm{C}-\mathrm{H}$ asym stretch, $\mathrm{v}_{\mathrm{as}}(\mathrm{H}-\mathrm{C}(2)), \mathrm{NCH}_{3} \mathrm{HCH}$ asym str & {$[25,26,29]$} \\
\hline & $3170(\mathrm{vw})$ & $\mathrm{H}-\mathrm{C}-\mathrm{C}-\mathrm{H}$ asym stretch, $v_{\mathrm{as}}(\mathrm{H}-\mathrm{C}(4)), v_{\mathrm{as}}(\mathrm{H}-\mathrm{C}(5))$ & {$[25,26]$} \\
\hline
\end{tabular}

\subsubsection{Region $1000-45 \mathrm{~cm}^{-1}$}

In this region (Figure.8), we observe the characteristic modes of $\mathrm{H}_{2} \mathrm{PO}_{4}{ }^{-}$anion. The bands appearing in the zone $200-50 \mathrm{~cm}^{-1}$ assigned to intermolecular vibrations [18,22]. The modes between 230 and $655 \mathrm{~cm}^{-1}$ are assigned to $\mathrm{NCH}_{3}$ for both of ILs $[18,25,26,43,44]$. The symmetric bending modev 2 of dihydrogenophosphate anion is observed at $417 \mathrm{~cm}^{-1}$. The bending vibration of the $\mathrm{P}-\mathrm{O}$ group gives a very weak to weak band in the region $600-400 \mathrm{~cm}^{-1}$ for the $\mathrm{H}_{2} \mathrm{PO}_{4}^{-}$anion [33]. In addition, we notice the presence of the following vibrational modes: $705,875,901$ and $945 \mathrm{~cm}^{-1}$ assigned to $\mathrm{PO}_{2}$ symmetricstretching, $\mathrm{POH}$ symmetric and antisymmetric stretching respectively. 


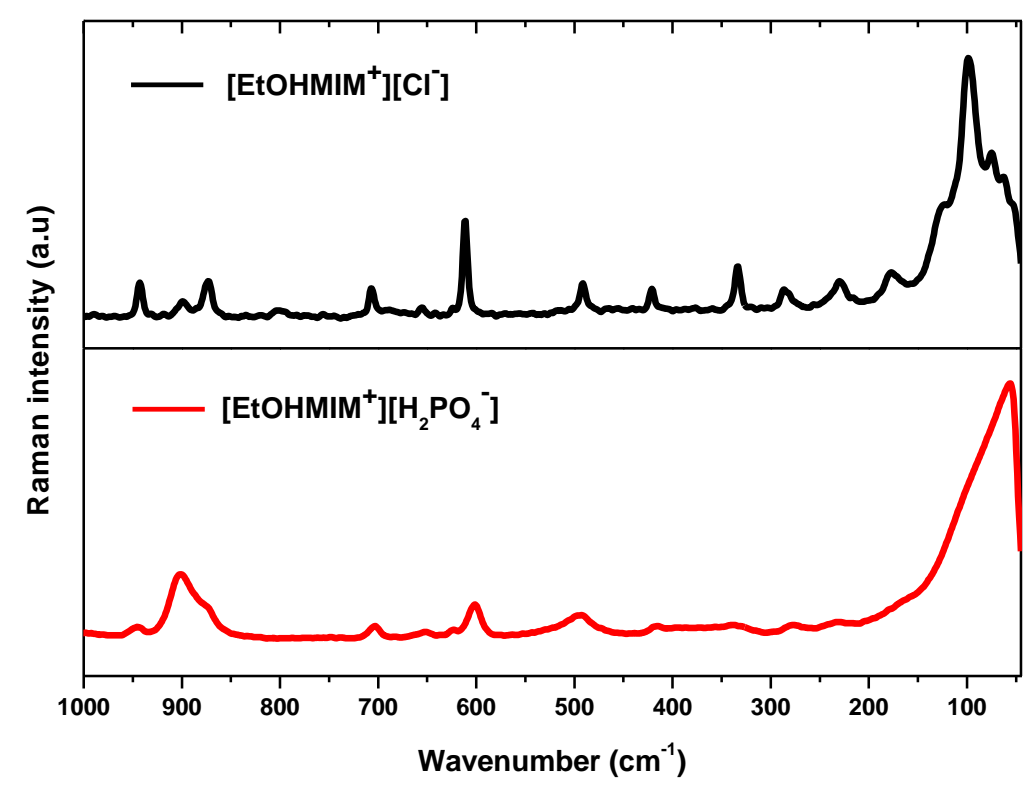

Figure.8. Raman spectra of $\left[\mathrm{EtOHMIM}^{+}\right]\left[\mathrm{Cl}^{-}\right]$and $\left[\mathrm{EtOHMIM}^{+}\right]\left[\mathrm{H}_{2} \mathrm{PO}_{4}^{-}\right]$in the spectral range $1000-45 \mathrm{~cm}^{-1}$.

\subsubsection{Region $1700-1000 \mathrm{~cm}^{-1}$}

In this region (Figure.9), both of ILs have almost similar intensities without having a big shift in frequency of the vibrational mode. In the range $1300-1000 \mathrm{~cm}^{-1}$, we observe the vibrational mode attributed to $\mathrm{C}$-C of the cation and the vibrations of the $\mathrm{H}_{2} \mathrm{PO}_{4}{ }^{-}$anion. Two $\mathrm{PO}_{2}$ symmetric stretching modes are expected between 1072 and $1194 \mathrm{~cm}^{-1}$, P-O stretching in $1072 \mathrm{~cm}^{-1}$ and $\mathrm{P}=\mathrm{O}$ symmetric stretching in $1340 \mathrm{~cm}^{-1}$ $[33,36,45,49]$. The Raman modes at $1347 \mathrm{~cm}^{-1}$ can be assigned to $\left(\mathrm{N}^{2} \mathrm{CH}_{2} \mathrm{CN}\right.$ stretching vibrations for the $\mathrm{Cl}^{-}$ anion which is transformed for the $\mathrm{H}_{2} \mathrm{PO}_{4}{ }^{-}$anion to 1340 and $1356 \mathrm{~cm}^{-1}$ modes[18,43,44]. The bands appearing in the zone $1435-1389 \mathrm{~cm}^{-1}$ assigned to imidazolium ring: $\mathrm{C}-\mathrm{N}, \mathrm{C}=\mathrm{N}$ stretching banding. For [EtOHMIM $\left.{ }^{+}\right]\left[\mathrm{Cl}^{-}\right]$we observe four modes in $1435,1445,1466$ and $1568 \mathrm{~cm}^{-1}$ assigned to $\mathrm{NCH}_{3} \mathrm{CN}$ stretching while for $\left[\right.$ EtOHMIM $\left.{ }^{+}\right]\left[\mathrm{H}_{2} \mathrm{PO}_{4}\right]$ ]this mode was observed at 1453 and $1567 \mathrm{~cm}^{-1}$. 


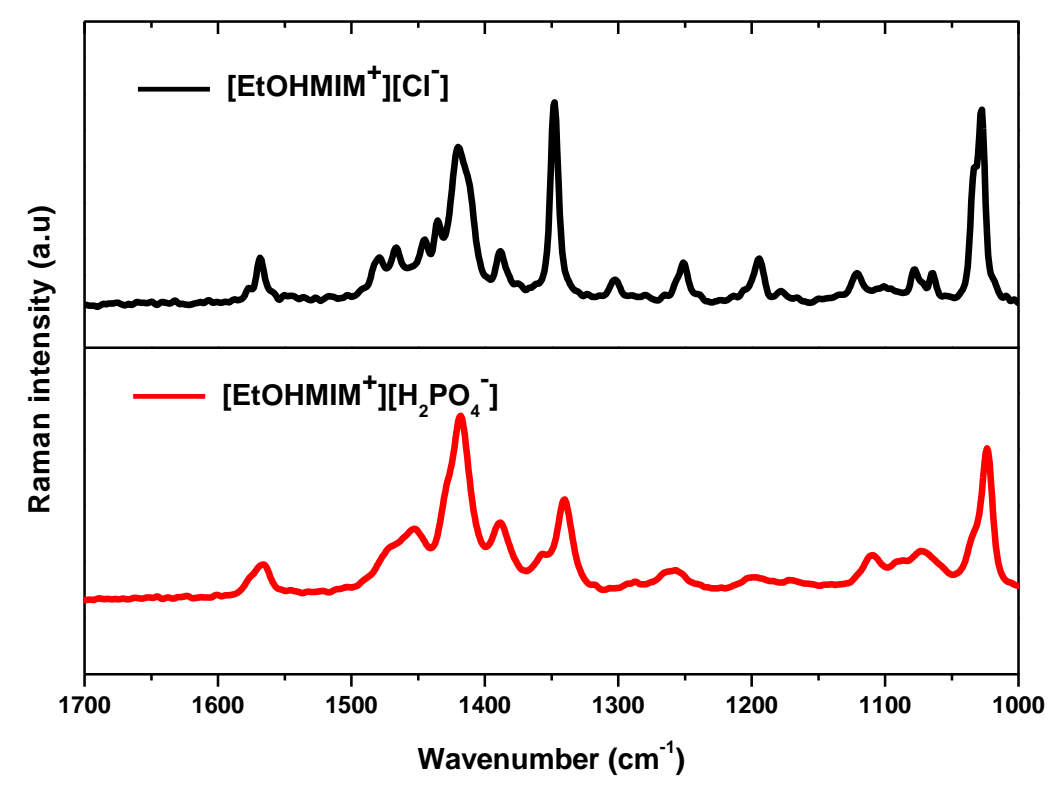

Figure.9. Raman spectra of $\left[\mathrm{EtOHMIM}^{+}\right]\left[\mathrm{Cl}^{-}\right]$and $\left[\mathrm{EtOHMIM}^{+}\right]\left[\mathrm{H}_{2} \mathrm{PO}_{4}^{-}\right]$in the spectral range $1700-1000 \mathrm{~cm}^{-1}$.

\subsubsection{Region $3500-2700 \mathrm{~cm}^{-1}$}

It should be noted that in this region, the only vibrational mode of the cation is observed(Figure.10). The bands due to the vibrations of $\mathrm{CH}_{3}$ and symmetrical stretching $\mathrm{NCH}_{3}$ occurs at $3000-2700 \mathrm{~cm}^{-1}$ and are of very low to medium intensity. For the $\left[\mathrm{EtOHMIM}^{+}\right]\left[\mathrm{Cl}^{-}\right]$the Raman modes at 3037 and $3054 \mathrm{~cm}^{-1}$ attributed to $\mathrm{C}-\mathrm{H}$ stretching not available for $\left[\mathrm{EtOHMIM}^{+}\right]\left[\mathrm{H}_{2} \mathrm{PO}_{4}^{-}\right]$. The modes at 3104 and $3143 \mathrm{~cm}^{-1}$ of $\left[\mathrm{EtOHMIM}^{+}\right]\left[\mathrm{Cl}^{-}\right]$are assigned to $\mathrm{H}-\mathrm{C}-\mathrm{C}-\mathrm{H}$ antisymmetric stretching and vibrational mode of antisymmetric $(\mathrm{H}-\mathrm{C}(2))$ which are observed at $3105 \mathrm{~cm}^{-1}$ for $\left[\right.$ EtOHMIM$\left.{ }^{+}\right]\left[\mathrm{H}_{2} \mathrm{PO}_{4}{ }^{-}\right]$. We also observe in the peak of $\left[\right.$ EtOHMIM $\left.{ }^{+}\right]\left[\mathrm{H}_{2} \mathrm{PO}_{4}{ }^{-}\right]$centered at $3170 \mathrm{~cm}^{-1}$ the presence of $\mathrm{H}-\mathrm{C}-\mathrm{C}-\mathrm{H}$ antisymmetric stretching with vibrational mode assigned to antisymmetric $(\mathrm{H}-\mathrm{C}(4))$ and $(\mathrm{H}-\mathrm{C}(5))$ of imidazolium. 


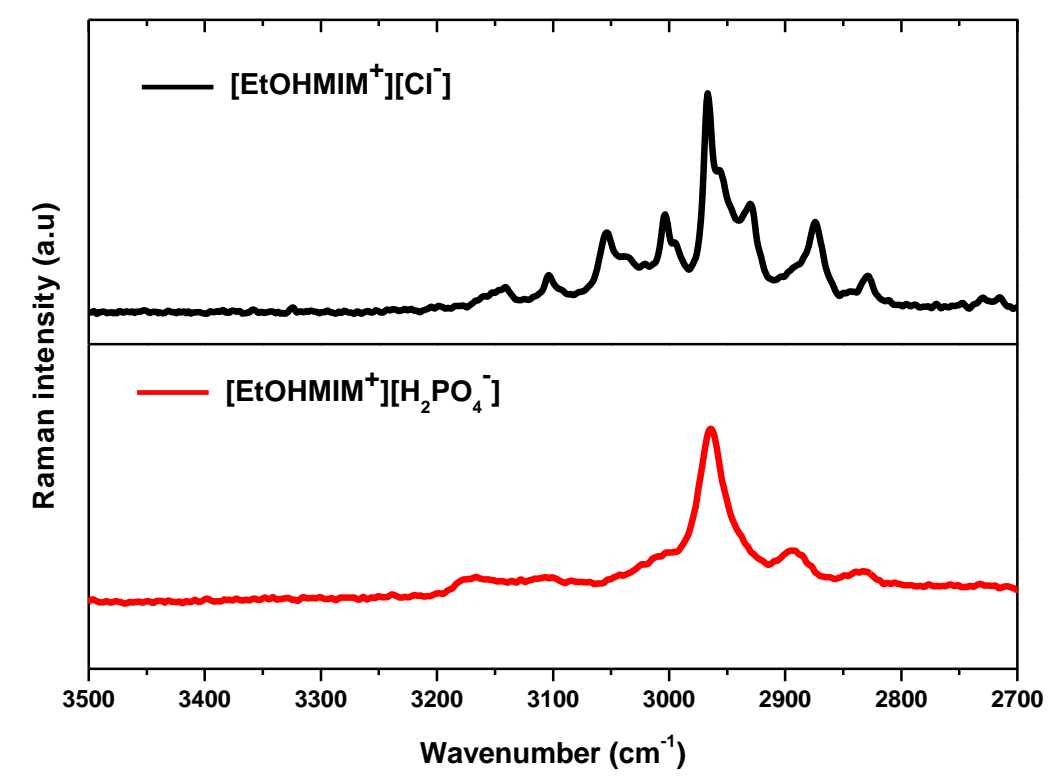

Figure.10. Raman spectra of $\left[\mathrm{EtOHMIM}^{+}\right][\mathrm{Cl}]$ and $\left[\mathrm{EtOHMIM}^{+}\right]\left[\mathrm{H}_{2} \mathrm{PO}_{4}{ }^{-}\right]$in the spectral range $3500-2700 \mathrm{~cm}^{-1}$.

\section{Thermal properties}

The DSC thermograms for $\left[\right.$ EtOHMIM $\left.^{+}\right]\left[\mathrm{Cl}^{-}\right]$and $\left[\mathrm{EtOHMIM}^{+}\right]\left[\mathrm{H}_{2} \mathrm{PO}_{4}^{-}\right]$are shown in Figure.11 and the thermogravimetric analysis curves (TGA) and the derivative thermogravimetric curves (DTG) are shown in Figure.12. The mass spectrometric diagram of gas escaped from ionic liquid $\left[\mathrm{EtOHMIM}^{+}\right]\left[\mathrm{Cl}^{-}\right]$and $\left[\mathrm{EtOHMIM}^{+}\right]\left[\mathrm{H}_{2} \mathrm{PO}_{4}{ }^{-}\right]$are presented in Figure.13. The thermal gravimetric parameters extracted from these curves are presented in Table 3 .

\subsection{DSC Thermogram}

Concerning [EtOHMIM $\left.{ }^{+}\right]\left[\mathrm{Cl}^{-}\right]$we can see from Figure.11.aand Table 3that while heating from lower temperature $\left(-100^{\circ}\right)$ we observe a glass transitions $\mathrm{Tg}=-58{ }^{\circ} \mathrm{C}$, then an exothermic peak onset at $-36.2^{\circ} \mathrm{C}$ with an enthalpy of $24.21 \mathrm{~J} / \mathrm{g}$ that corresponds to the crystallization of the sample and then an endothermic peak onset at $64{ }^{\circ} \mathrm{C}$ in the heating phase corresponding to the melting point of $\left[\mathrm{EtOHMIM}^{+}\right]\left[\mathrm{Cl}^{-}\right]$with an enthalpy of $79.44 \mathrm{~J} / \mathrm{g}$.

In the DSC curve (Figure.11.b), [EtOHMIM $\left.{ }^{+}\right]\left[\mathrm{H}_{2} \mathrm{PO}_{4}{ }^{-}\right]$has not showed a glass transition on heating scan, then an exothermic peak onset at $77^{\circ} \mathrm{C}$.An endothermic peak onset at $84{ }^{\circ} \mathrm{C}$ was observed in the heating phase corresponding to the melting point of $\left[\mathrm{EtOHMIM}^{+}\right]\left[\mathrm{H}_{2} \mathrm{PO}_{4}{ }^{-}\right]$.We observe also another endothermic 
peak at $117^{\circ} \mathrm{C}$ that corresponds probably to the melting point of a second morphology of the same sample[50-51]. The temperatures of decomposition and total decomposition are indicated in Table 3.

(a)

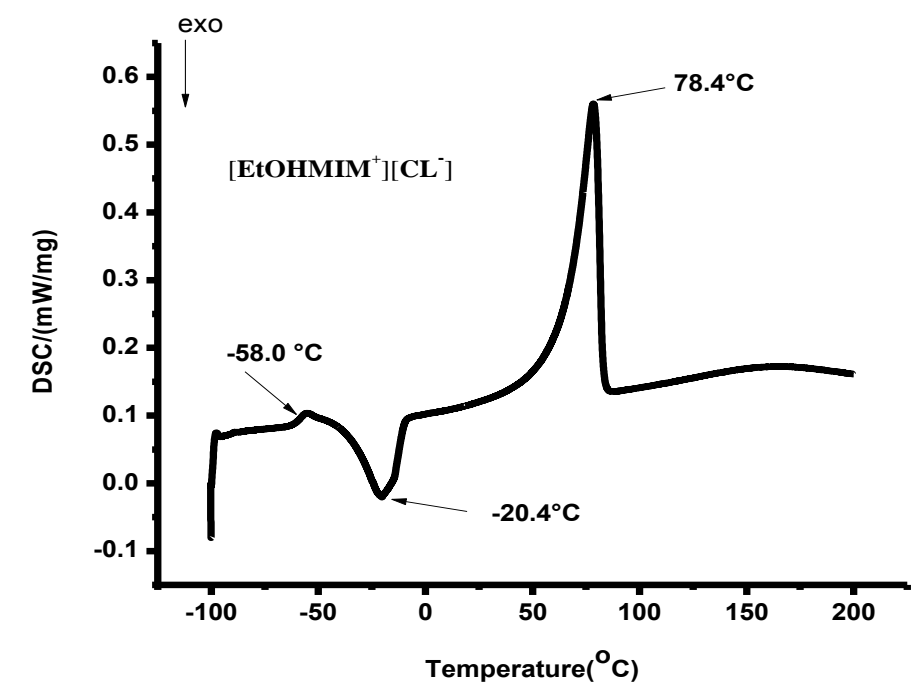

(b)

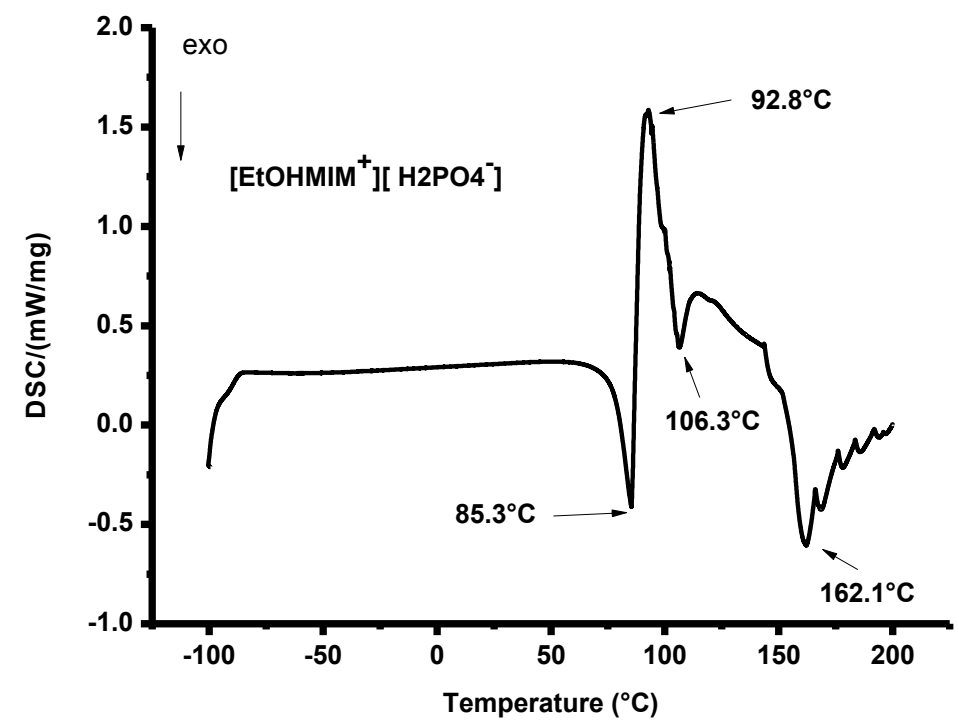

Figure.11. DSC thermograms of ionic liquids from $-100{ }^{\circ} \mathrm{C}$ to $200{ }^{\circ} \mathrm{C}$ $\left[\mathrm{EtOHMIM}^{+}\right]\left[\mathrm{Cl}^{-}\right]$(a) and $\left[\mathrm{EtOHMIM}^{+}\right]\left[\mathrm{H}_{2} \mathrm{PO}_{4}^{-}\right](\mathrm{b})$ 
(a)

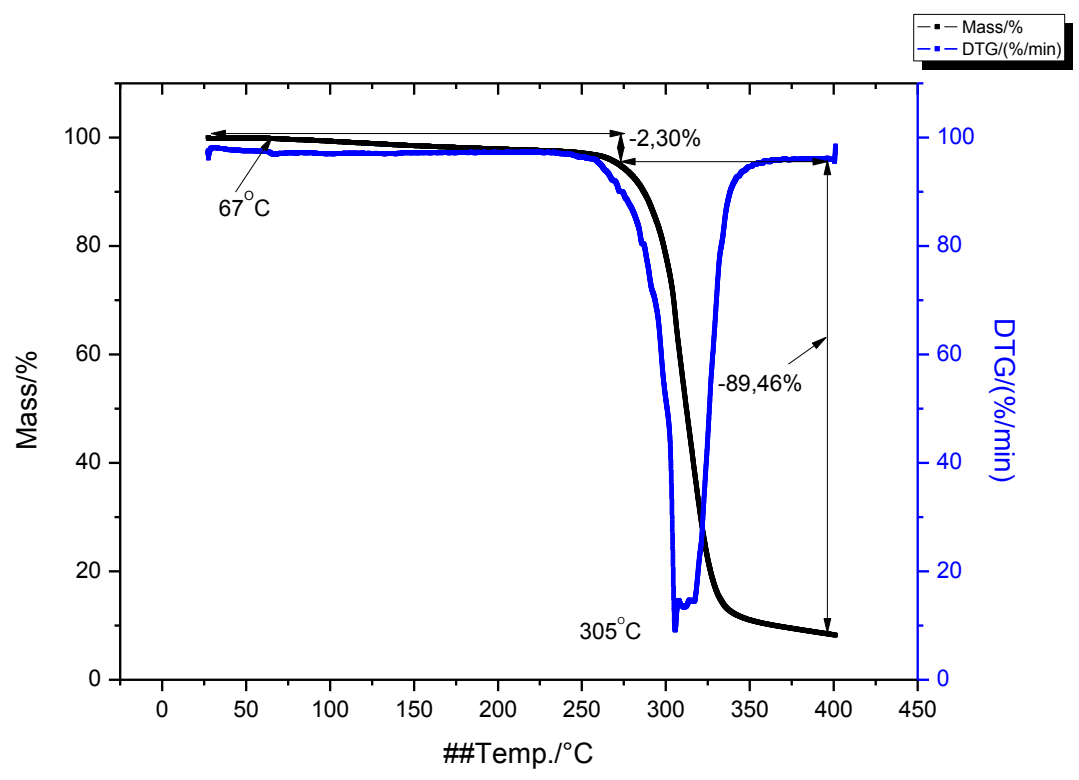

(b)

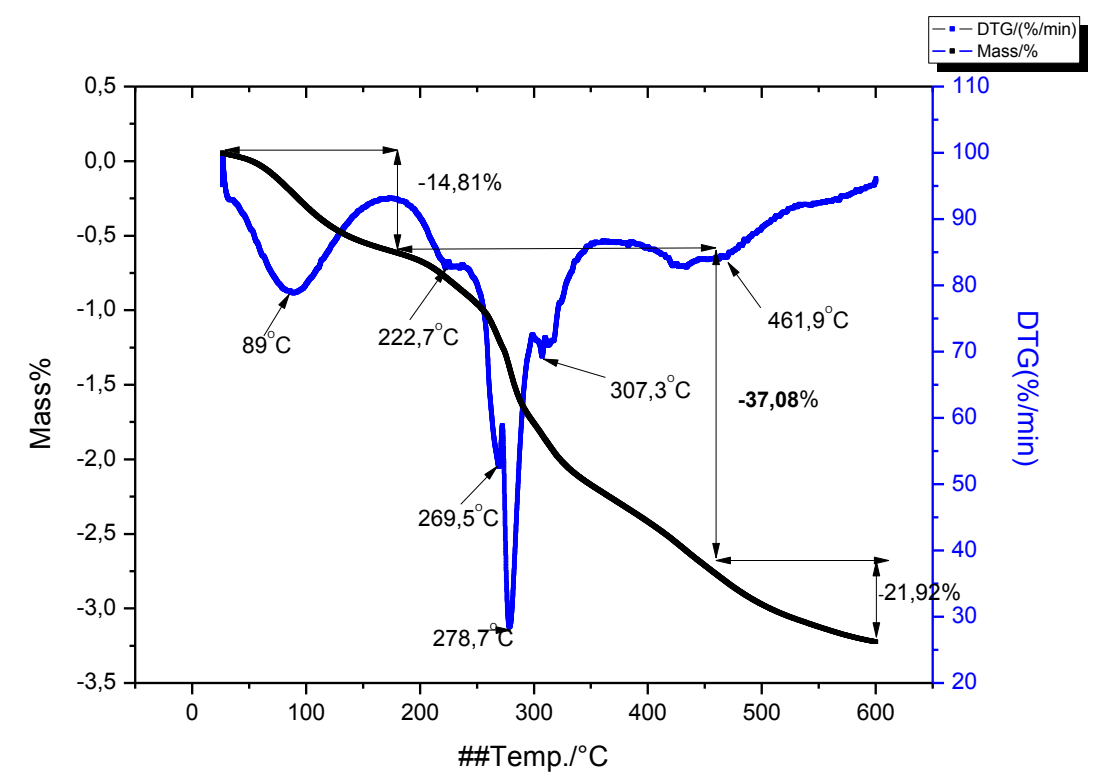

Figure.12. TGA and DTG of ionic liquids $\left[\mathrm{EtOHMIM}^{+}\right]\left[\mathrm{Cl}^{-}\right]\left(20^{\circ} \mathrm{C}\right.$ to $\left.400{ }^{\circ} \mathrm{C}\right)(\mathrm{a})$ and $\left[\mathrm{EtOHMIM}^{+}\right]\left[\mathrm{H}_{2} \mathrm{PO}_{4}{ }^{-}\right]\left(20{ }^{\circ} \mathrm{C}\right.$ to $\left.600{ }^{\circ} \mathrm{C}\right)(\mathrm{b})$. 
(a)

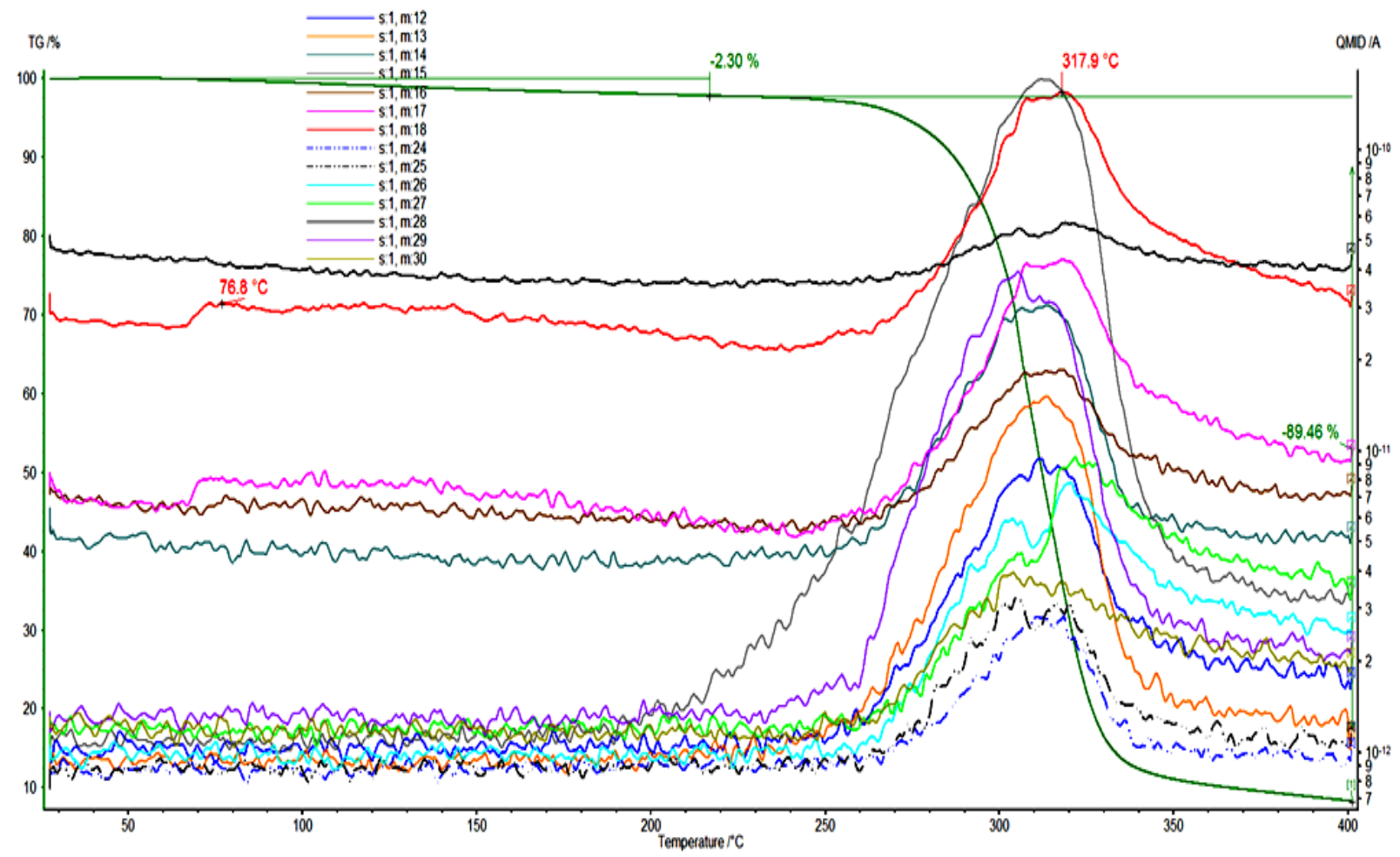

(b)

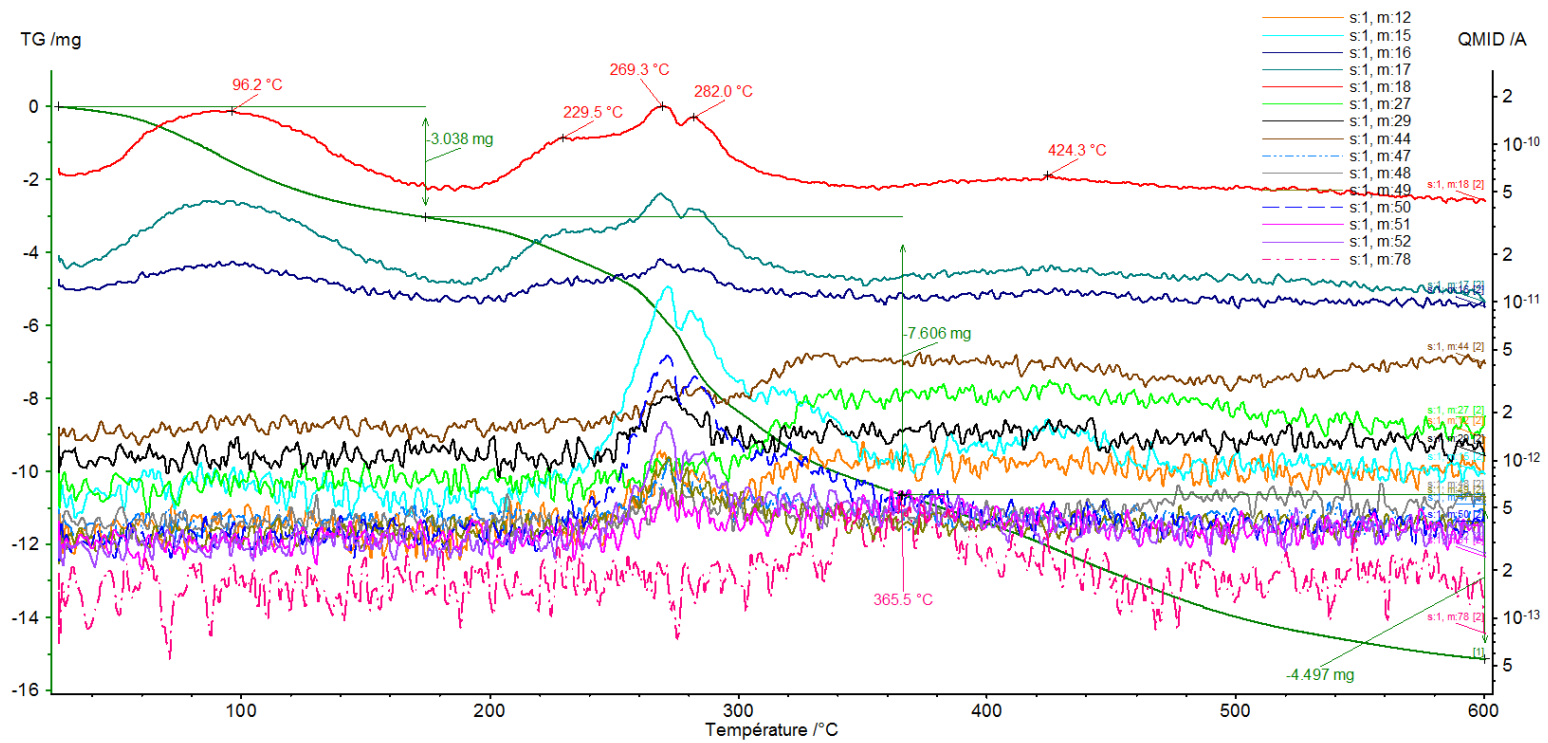

Figure.13. Mass spectrometric diagram of gas escaped from $\left[\mathrm{EtOHMIM}^{+}\right]\left[\mathrm{Cl}^{-}\right]\left(20^{\circ} \mathrm{C}\right.$ to $\left.400{ }^{\circ} \mathrm{C}\right)(\mathrm{a})$ and $\left[\mathrm{EtOHMIM}^{+}\right]\left[\mathrm{H}_{2} \mathrm{PO}_{4}{ }^{-}\right]$ionic liquids $\left(20{ }^{\circ} \mathrm{C}\right.$ to $\left.600{ }^{\circ} \mathrm{C}\right)(\mathrm{b})$. 
Table 3Thermal properties of $\left[\mathrm{EtOHMIM}^{+}\right]\left[\mathrm{Cl}^{-}\right]$and $\left[\mathrm{EtOHMIM}^{+}\right]\left[\mathrm{H}_{2} \mathrm{PO}_{4}^{-}\right]$.

\begin{tabular}{cccccc}
\hline & $\operatorname{Tg}\left({ }^{\circ} \mathrm{C}\right)$ & $\operatorname{Tc}\left({ }^{\circ} \mathrm{C}\right)$ & $\operatorname{Tf}\left({ }^{\circ} \mathrm{C}\right)$ & $\operatorname{Td}\left({ }^{\circ} \mathrm{C}\right)$ & $\operatorname{Td}_{\mathrm{T}}\left({ }^{\circ} \mathrm{C}\right)$ \\
Ionic Liquids & & & & & \\
\hline$\left[\right.$ EtOHMIM $\left.^{+}\right]\left[\mathrm{Cl}{ }^{-}\right]$ & -58 & -36.2 & 64 & 250 & 317 \\
{$\left[\mathrm{EtOHMIM}^{+}\right]\left[\mathrm{H}_{2} \mathrm{PO}_{4}{ }^{-}\right]$} & - & 77 & 84 & 264 & 365 \\
\hline
\end{tabular}

\subsection{Thermal Stability}

According to the TGA and DTG curves in (Figure.12.a), the thermal stability of $\left[\mathrm{EtOHMIM}^{+}\right]\left[\mathrm{Cl}^{-}\right]$covers a large domain of temperature between $-100^{\circ} \mathrm{C}$ and $250^{\circ} \mathrm{C}$. A mass loss started in two steps between $20^{\circ} \mathrm{C}$ and $400^{\circ} \mathrm{C}$. For the first step, a mass loss of $2.30 \%$ begins at nearly $67^{\circ} \mathrm{C}$ and ends at a temperature of $253^{\circ} \mathrm{C}$. This loss corresponding to the release of the $\mathrm{H}_{2} \mathrm{O}$ gas identified from the mass spectrometry curve. The second step (from $253^{\circ} \mathrm{C}$ to about $334^{\circ} \mathrm{C}$ ), a loss of $89.46 \%$, corresponding to the release of $\mathrm{CH}_{3}$ and $\mathrm{OH}$ and other fragments identified as gas from the mass spectrometry curve.

For the $\left[\mathrm{EtOHMIM}^{+}\right]\left[\mathrm{H}_{2} \mathrm{PO}_{4}^{-}\right]$sample, the TGA and DTG thermograms (Figure12.b) show that this compound is steady below $50^{\circ} \mathrm{C}$ and undergo change from this temperature in three steps, leaving a reddish residue of $26.19 \%$ from the initial mass at $600^{\circ} \mathrm{C}$. The first step begins at almost $50^{\circ} \mathrm{C}$ with a mass loss of $14.81 \%$ and ends at a temperature of $200^{\circ} \mathrm{C}$ corresponding to the release of $\mathrm{H}_{2} \mathrm{O}$ as a gas identified by the mass spectrometry curve. The second step begins at $200^{\circ} \mathrm{C}$ and ends at approximately $360^{\circ} \mathrm{C}$ with a loss of $37.08 \%$ corresponding to the release of $\mathrm{H}_{2} \mathrm{O}, \mathrm{CH}_{3}, \mathrm{OH}$ and other fragments identified as gases from the mass spectrometry curve, and the third step between 360 and $600^{\circ} \mathrm{C}$ with a loss of $21.92 \%$.

\section{Conclusion}

In this study, we synthesized a new hydroxyl-functionalized ionic liquid based on 1-(hydroxyethyl)-3methylimidazolium dihydrogenophosphate with a yield of $98 \%$ in two-steps of synthesis where the anion $\mathrm{Cl}^{-}$ was exchanged by $\mathrm{H}_{2} \mathrm{PO}_{4} \cdot{ }^{-1} \mathrm{H}$ and ${ }^{13} \mathrm{C}-\mathrm{NMR}$ spectroscopy measurements confirm the geometry and purity of the targeted ILs. Also, both compounds were characterized by FTIR/ATR, FT Raman and TGA / DTA/ DSC thermal measurements DSC. The anion seems to play an important role in the thermal stability of the compound as well as on its vibrational behaviour. The results of vibrational spectroscopy and DSC are compared with those obtained on the same intermediate compound $\left[\mathrm{EtOHMIM}^{+}\right]\left[\mathrm{Cl}^{-}\right]$. The final compound 
i.e. $\left[\mathrm{EtOHMIM}^{+}\right]\left[\mathrm{H}_{2} \mathrm{PO}_{4}^{-}\right]$shows more interesting vibrational and thermal properties due the type of anion.

\section{Acknowledgment}

The authors thank the ATRST-DGRSDT (Algeria) for the financial support and the Walloon Agricultural Research Center (CRA-W), who participated to FT-RAMAN and FTIR/ATR measurements.

\section{References}

[1] Betz, D., Altmann, P., Cokoja, M., Herrmann, W. A., \&Kühn, F. E. (2011). Recent advances in oxidation catalysis using ionic liquids as solvents. Coordination Chemistry Reviews, 255(13-14), 1518-1540.

[2] Haddad, B., Villemin, D., \&Belarbi, E. H. (2014). Synthesis of palladium-bidentate complex and its application in Sonogashira and Suzuki coupling reactions.Chemical Papers, 68(5), 656-661.

[3] Fraga-Dubreuil, J., \&Bazureau, J. P. (2001).Grafted ionic liquid-phase-supported synthesis of small organic molecules.Tetrahedron Letters, 42(35), 6097-6100.

[4] Debdab, M., Mongin, F., \&Bazureau, J. P. (2006).Ionic-liquid-supported synthesis of amines and derivatives.Synthesis, 2006(23), 4046-4052.

[5] Nie, N., Zheng, D., Dong, L., \& Li, Y. (2012). Thermodynamic properties of the water+ 1-(2hydroxylethyl)-3-methylimidazolium chloride system.Journal of Chemical \& Engineering Data, 57(12), 3598-3603.

[6] Qu, Y., Huang, C., Song, Y., Zhang, J., \& Chen, B. (2012).Efficient dehydration of glucose to 5hydroxymethylfurfural catalyzed by the ionic liquid, 1-hydroxyethyl-3-methylimidazolium tetrafluoroborate.Bioresource technology, 121, 462-466.

[7] Najdanovic-Visak, V., Rodriguez, A., Visak, Z. P., Rosa, J. N., Afonso, C. A., da Ponte, M. N., \&Rebelo, L. P. N. (2007). Co-solvent effects in LLE of 1-hydroxyethyl-3-methylimidazolium based ionic liquids+ 2propanol+ dichloromethane or 1, 2-dichloroethane. Fluid phase equilibria, 254(1-2), 35-41.

[8] Jalili, A. H., Mehdizadeh, A., Shokouhi, M., Sakhaeinia, H., \&Taghikhani, V. (2010).Solubility of CO2 in 1-(2-hydroxyethyl)-3-methylimidazolium ionic liquids with different anions.The Journal of Chemical Thermodynamics, 42(6), 787-791.

[9] Zhang, S., Qi, X., Ma, X., Lu, L., Zhang, Q., \& Deng, Y. (2012). Investigation of cation-anion interaction in 1-(2-hydroxyethyl)-3-methylimidazolium-based ion pairs by density functional theory calculations and experiments. Journal of Physical Organic Chemistry, 25(3), 248-257.

[10] Sakhaeinia, H., Taghikhani, V., Jalili, A. H., Mehdizadeh, A., \&Safekordi, A. A. (2010). Solubility of $\mathrm{H} 2 \mathrm{~S}$ in 1-(2-hydroxyethyl)-3-methylimidazolium ionic liquids with different anions.Fluid phase equilibria, 298(2), 303-309.

[11] Panja, S. K., Haddad, B., \& Kiefer, J. (2018). Clusters of the Ionic Liquid 1-Hydroxyethyl-3-methylimidazolium Picrate: From Theoretical Prediction in the Gas Phase to Experimental Evidence in the Solid State. ChemPhysChem, 19(22), 3061-3068.

[12] Ebrahimi, M., Ahmadi, A. N., Safekordi, A. A., Fateminasab, F., \&Mehdizadeh, A. (2014). Liquidliquid equilibrium data for \{heptane+ aromatic+ 1-(2-hydroxyethyl)-3-methylimidazolium bis (trifluoromethylsulfonyl) imide ([hemim][NTf2])\} ternary systems. Journal of Chemical \& Engineering Data, 59(2), 197-204.

[13] Panja, S. K., Haddad, B., Debdab, M., Kiefer, J., Chaker, Y., Bresson, S., \&Paolone, A. (2019). Cluster formation through hydrogen bond bridges across chloride anions in a hydroxyl-functionalized ionic liquid. ChemPhysChem, 20(7), 936-940.

[14] Sun, J., Zhang, S., Cheng, W., \&Ren, J. (2008). Hydroxyl-functionalized ionic liquid: a novel efficient catalyst for chemical fixation of CO2 to cyclic carbonate. Tetrahedron Letters, 49(22), 3588-3591. 
[15] Reslan, M., \&Kayser, V. (2018).Ionic liquids as biocompatible stabilizers of proteins.Biophysical reviews, 10(3), 781-793.

[16] Merouani, S., Hamdaoui, O., \& Haddad, B. (2018). Acoustic cavitation in 1-butyl-3-methylimidazolium bis (triflluoromethyl-sulfonyl) imide based ionic liquid. Ultrasonicssonochemistry, 41, 143-155.

[17] Fan, Y., Wang, X., Zhang, L., Li, J., Yang, L., Gao, P., \& Zhou, Z. (2018). Lipase-catalyzed synthesis of biodiesel in a hydroxyl-functionalized ionic liquid.Chemical Engineering Research and Design, 132, 199207.

[18] Paschoal, V. H., Faria, L. F., \&Ribeiro, M. C. (2017).Vibrational spectroscopy of ionic liquids.Chemical reviews, 117(10), 7053-7112.

[19] Perez-Olivan, S., Solans, C., Garcia, M. A., Pinilla, I., Honrubia, F., \&Bregante, M. A. (2000). Determination of grepafloxacin in plasma samples by HPLC: Application to clinical pharmacokinetic studies. Chromatographia, 51(1-2), 25-28.

[20] Lamrini, R., Crouzet, J. M., Francina, A., Guilluy, R., Steghens, J. P., \& Brazier, J. L. (1994). Evaluation of hydroxyl radicals production using $13 \mathrm{CO} 2$ gas chromatography-isotope ratio mass spectrometry. Analytical biochemistry, 220(1), 129-136.

[21] Chaker, Y., Ilikti, H., Debdab, M., Moumene, T., Belarbi, E. H., Wadouachi, A., ...\&Bresson, S. (2016). Synthesis and characterization of 1-(hydroxyethyl)-3-methylimidazolium sulfate and chloride ionic liquids.Journal of Molecular Structure, 1113, 182-190.

[22] Haddad, B., Kiefer, J., Brahim, H., Belarbi, E. H., Villemin, D., Bresson, S., ...\& Palumbo, O. (2018). Effects of $\mathrm{C}$ (2) methylation on thermal behavior and interionic interactions in imidazolium-based ionic liquids with highly symmetric anions.Applied Sciences, 8(7), 1043.

[23] Hadji, D., Haddad, B., Brandán, S. A., Panja, S. K., Paolone, A., Drai, M., ... \&Rahmouni, M. (2020). Synthesis, NMR, Raman, thermal and nonlinear optical properties of dicationic ionic liquids from experimental and theoretical studies.Journal of Molecular Structure, 1220, 128713.

[24] Boumediene, M., Haddad, B., Paolone, A., Assenine, M. A., Villemin, D., Rahmouni, M., \&Bresson, S. (2020). Synthesis, conformational studies, vibrational spectra and thermal properties, of new 1, 4(phenylenebis (methylene) bis (methyl-imidazolium) ionic liquids.Journal of Molecular Structure, 1220, 128731 .

[25] Haddad, B., Paolone, A., Drai, M., Boumediene, M., Villemin, D., Belarbi, E. H., ...\& Abbas, O. (2019). Para-xylyl linked bis-imidazolium ionic liquids: A study of the conformers of the cation and of the anion-cation hydrogen bonding. Journal of Molecular Structure, 1175, 175-184.

[26] Boumediene, M., Haddad, B., Paolone, A., Drai, M., Villemin, D., Rahmouni, M., ...\& Abbas, O. (2019). Synthesis, thermal stability, vibrational spectra and conformational studies of novel dicationic metaxylyl linked bis-1-methylimidazolium ionic liquids. Journal of Molecular Structure, 1186, 68-79.

[27] Haddad, B., Mokhtar, D., Goussem, M., Belarbi, E. H., Villemin, D., Bresson, S., ...\& Kiefer, J. (2017). Influence of methyl and propyl groups on the vibrational spectra of two imidazolium ionic liquids and their non-ionic precursors. Journal of Molecular Structure, 1134, 582-590.

[28] Ahmed, A., Chaker, Y., Belarbi, E. H., Abbas, O., Chotard, J. N., Abassi, H. B., ... \&Bresson, S. (2018). XRD and ATR/FTIR investigations of various montmorillonite clays modified by monocationic and dicationicimidazolium ionic liquids. Journal of Molecular Structure, 1173, 653-664.

[29] Kausteklis, J., Aleksa, V., Iramain, M. A., \&Brandán, S. A. (2018). Effect of cation-anion interactions on the structural and vibrational properties of 1-buthyl-3-methyl imidazolium nitrate ionic liquid. Journal of Molecular Structure, 1164, 563-576.

[30] Haddad, B., Paolone, A., Villemin, D., Lohier, J. F., Drai, M., Bresson, S., ...\&Belarbi, E. H. (2018). para-Xylyl bis-1-methylimidazolium bis (trifluoromethanesulfonyl) imide: Synthesis, crystal structure, thermal stability, vibrational studies. Journal of MolecularLiquids, 260, 391-402. 
[31] Panja, S. K., Boumediene, H., Drai, M., Villemin, D., \& Bresson, S. (2018). Probing effect of weak Hbonding on conformational change in ionic liquid: Experimental and DFT studies. Journal of Molecular Liquids, 266, 727-732.

[32] Moumene, T., Belarbi, E. H., Haddad, B., Villemin, D., Abbas, O., Khelifa, B., \&Bresson, S. (2015). Study of imidazoliumdicationic ionic liquids by Raman and FTIR spectroscopies: The effect of the nature of the anion. Journal of Molecular Structure, 1083, 179-186.

[33] Ahmed, A. B., Feki, H., Abid, Y., Boughzala, H., Minot, C., \&Mlayah, A. (2009).Crystal structure, vibrational spectra and theoretical studies of L-histidiniumdihydrogen phosphate-phosphoric acid. Journal of Molecular Structure, 920(1-3), 1-7.

[34] Haddad, B., Paolone, A., Villemin, D., Taqiyeddine, M., Belarbi, E. H., Bresson, S., ...\& Kiefer, J. (2017). Synthesis, conductivity, and vibrational spectroscopy of tetraphenylphosphoniumbis (trifluoromethanesulfonyl) imide. Journal of Molecular Structure, 1146, 203-212.

[35]Assenine, M. A., Haddad, B., Paolone, A., Brandán, S. A., Villemin, D., Boumediene, M., ...\&Bresson, S. (2021). Experimental and DFT studies on structure, spectroscopic and thermal properties of N-Methyl-N, N, N-trioctylammonium chloride ionic liquid.Journal of Molecular Structure, 1230, 129625.

[36] Okura, T., Miyachi, T., \&Monma, H. (2006).Properties and vibrational spectra of magnesium phosphate glasses for nuclear waste immobilization. Journal of the European Ceramic Society, 26(4-5), 831-836.

[37] Sudha, S., Karabacak, M., Kurt, M., Cinar, M., \&Sundaraganesan, N. (2011).Molecular structure, vibrational spectroscopic, first-order hyperpolarizability and HOMO, LUMO studies of 2aminobenzimidazole. SpectrochimicaActa Part A: Molecular and Biomolecular Spectroscopy, 84(1), 184195.

[38] Haddad, B., Brandán, S. A., Assenine, M. A., Paolone, A., Villemin, D., \&Bresson, S. (2020). Bidentatecation-anion coordination in the ionic liquid 1-ethyl-3-methylimidazolium hexafluorophosphate supported by vibrational spectra and NBO, AIM and SQMFF calculations. Journal of Molecular Structure, 1212, 128104.

[39]Fetouhi, B., Haddad, B., Brandán, S. A., Paolone, A., Villemin, D., Boumediene, M., ...\&Bresson, S. (2021). Synthesis, molecular structure, and properties of DABCO bromide based ionic liquid combining spectroscopic studies with DFT calculations. Journal of Molecular Structure, 1233, 130102.

[40] Drai, M., Mostefai, A., Paolone, A., Haddad, B., Belarbi, E., Villemin, D., ...\&Rahmouni, M. (2017). Synthesis, experimental and theoretical vibrational studies of 1-methyl and 1, 2-dimethyl, 3-propyl imidazoliumbis (trifluoromethanesulfonyl) imide. Journal of Chemical Sciences, 129(6), 707-719.

[41] Guidara, S., Feki, H., \&Abid, Y. (2014).Molecular structure, NLO, MEP, NBO analysis and spectroscopic characterization of 2, 5-dimethylanilinium dihydrogen phosphate with experimental (FT-IR and FT-Raman) techniques and DFT calculations. SpectrochimicaActa Part A: Molecular and BiomolecularSpectroscopy, 133, 856-866.

[42] Emmanuel, V., Odile, B., \& Céline, R. (2015).FTIR spectroscopy of woods: A new approach to study the weathering of the carving face of a sculpture. SpectrochimicaActa Part A: Molecular and Biomolecular Spectroscopy, 136, 1255-1259.

[43] Heimer, N. E., Del Sesto, R. E., Meng, Z., Wilkes, J. S., \& Carper, W. R. (2006). Vibrational spectra of imidazoliumtetrafluoroborate ionic liquids. Journal of molecular liquids, 124(1-3), 84-95.

[44] Kadari, M., Belarbi, E. H., Moumene, T., Bresson, S., Haddad, B., Abbas, O., \&Khelifa, B. (2017).Comparative study between 1-Propyl-3-methylimidazolium bromide and trimethylenebis- 
methylimidazolium bromide ionic liquids by FTIR/ATR and FT-RAMAN spectroscopies. Journal of Molecular Structure, 1143, 91-99.

[45] Frost, R. L., Xi, Y., Beganovic, M., Belotti, F. M., \&Scholz, R. (2013). Vibrational spectroscopy of the phosphate mineral lazulite- $(\mathrm{Mg}, \mathrm{Fe}) \mathrm{Al} 2$ (PO4) $2 \cdot(\mathrm{OH}) 2$ found in the Minas Gerais, Brazil. SpectrochimicaActa Part A: Molecular and Biomolecular Spectroscopy, 107, 241-247.

[46] Moumene, T., Belarbi, E. H., Haddad, B., Villemin, D., Abbas, O., Khelifa, B., \&Bresson, S. (2014). Vibrational spectroscopic study of ionic liquids: Comparison between monocationic and dicationicimidazolium ionic liquids. Journal of Molecular Structure, 1065, 86-92.

[47] Kausteklis, J., Aleksa, V., Iramain, M. A., \&Brandán, S. A. (2019). DFT and vibrational spectroscopy study of 1-butyl-3-methylimidazolium trifluoromethanesulfonate ionic liquid. Journal of Molecular Structure, 1175, 663-676.

[48] Katsyuba, S. A., Zvereva, E. E., Vidiš, A., \& Dyson, P. J. (2007).Application of density functional theory and vibrational spectroscopy toward the rational design of ionic liquids. The Journal of Physical Chemistry A, 111(2), 352-370.

[49] Stutman, J. M., Termine, J. D., \& Posner, A. S. (1965).Vibrational spectra and structure of the phosphate ion in some calcium phosphates. Transactions of the New York Academy of Sciences, 27(6 Series II), 669-675.

[50] Haddad, B., Kachroudi, A., Turky, G., Belarbi, E. H., Lamouri, A., Villemin, D., ... \&Sylvestre, A. (2021). The interplay between molecular structure and dielectric properties in ionic liquids: A comparative study. Journal of Molecular Liquids, 324, 114674.

[51] Haddad, B., Moumene, T., Villemin, D., Lohier, J. F., \&Belarbi, E. H. (2016). Bis-methyl imidazoliummethylidenebis (trifluoromethanesulfonyl) imide, crystal structure, thermal and dielectric studies.Bulletin of Materials Science, 39(3), 797-801. 